\title{
Kinosternon subrubrum (Bonnaterre 1789) - Eastern Mud Turtle
}

\author{
Walter E. Meshaka, Jr. ${ }^{1}$, J. Whitfield Gibbons ${ }^{2}$, \\ Daniel F. Hughes ${ }^{3}$, Michael W. KLemens ${ }^{4}$, and John B. Iverson ${ }^{5}$ \\ ${ }^{1}$ State Museum of Pennsylvania, 300 North Street, Harrisburg,Pennsylvania 17120 USA [wmeshaka@pa.gov]; \\ ${ }^{2}$ Savannah River Ecology Lab, Drawer E, Aiken, South Carolina 29802 USA [wgibbons@uga.edu]; \\ ${ }^{3}$ University of Texas at El Paso, El Paso, Texas 79968 USA [dfhughes@miners.utep.edu]; \\ ${ }^{4}$ Department of Herpetology, American Museum of Natural History, \\ Central Park West at 79th Street, New York, New York 10024 USA [fenbois@aol.com]; \\ ${ }^{5}$ Department of Biology, Earlham College, Richmond, Indiana 47374 USA [johni@earlham.edu]
}

Summary. - The Eastern Mud Turtle, Kinosternon subrubrum (Family Kinosternidae), is a small (carapace length 85 to $120 \mathrm{~mm}$ ) polytypic species of the eastern and central United States. All three historically recognized subspecies (K. s. subrubrum, K. s. steindachneri, and K. s. hippocrepis) are semi-aquatic turtles that inhabit much of the U.S. Atlantic and Gulf Coastal Plains. The Florida taxon (K. s. steindachneri) appears to represent a distinct species, but we continue to treat it as a subspecies for the purposes of this account. Nesting seasons are shorter and clutch sizes (range: 1-8, modal: 2-3 eggs) larger in northern populations of the species, with up to four clutches annually in the South. Populations vary greatly in size and may comprise only a small segment or major portion of an aquatic turtle assemblage. Population declines are well documented in the Northeast and Midwest (K. s. subrubrum). Major threats to this species come from the disruption or destruction of freshwater and surrounding terrestrial habitats as well as road mortality, but it is not considered globally threatened at this time.

Distribution. - USA. Distributed in the eastern coastal plain from New York in the northeast throughout the Gulf Coast Plain to Texas in the southwest, north in the Mississippi Valley to Illinois and Indiana, and south through peninsular Florida.

Synonymy. - Testudo subrubra Lacepède 1788 (nomen suppressum), Testudo subrubra Bonnaterre 1789, Kinosternon subrubrum, Kinosternon subrubrum subrubrum,Testudo pensilvanica Gmelin 1789, Emydes pensilvanica, Kinosternon pensilvanicum, Cinosternum pensilvanicum, Emys pensylvanica Schweigger 1812 (nomen novum), Terrapene pensylvanica, Cistuda pensylvanica, Sternotherus pensylvanica, Kinosternum pensylvanicum, Cinosternon pensylvanicum, Clemmys (Cinosternon) pensylvanica, Kinosternon pensylvanicum, Cinosternum pensylvanicum, Kinosternon pennsylvanicum Bell 1825 (nomen novum), Emys (Kinosternon) pennsylvanica, Kinosternum pennsylvanicum, Cinosternon pennsylvanicum, Cinosternum pennsylvanicum, Cistudo pennsylvanica, Terrapene pennsylvanica, Thyrosternum pennsylvanicum, Kinosternon (Kinosternon) doubledayii Gray 1844, Kinosternon doubledayii,Kinosternum doubledayii,Cinosternum doubledayii,Cinosternondoubledayii, Kinosternon (Kinosternon) oblongum Gray 1844, Kinosternon oblongum, Cinosternum oblongum, Kinosternon punctatum Gray 1856, Cinosternum punctatum, Swanka fasciata Gray 1869.

SubSPECIES. - Three have until recently been recognized: 1) Kinosternon subrubrum subrubrum (Eastern Mud Turtle) (distribution: eastern coastal plains from New York to northern Florida, west to the Mississippi River and north to Illinois and Indiana); 2) K. s. hippocrepis (Mississippi Mud Turtle) (distribution: generally west of the Mississippi River from eastern Texas to southern Illinois) (synonymy: Kinosternon hippocrepis Gray 1856, Cinosternum hippocrepis, Cinosternon hippocrepis, Kinosternon subrubrum hippocrepis, Kinosternon louisianae Baur 1893, Cinosternum louisianae); and 3) K.s. steindachneri (Florida Mud Turtle) (distribution: peninsular Florida) (synonymy: Cinosternum steindachneri Siebenrock 1906, Kinosternon steindachneri, Kinosternon subrubrum steindachneri).

STATUS. - IUCN 2017 Red List: Least Concern (LC, assessed 2011); CITES: Not Listed; ESA: Not Listed; FNAI: G5 (Demonstrably Secure).

Taxonomy. - Kinosternon subrubrum was first described as Testudo subrubra by Lacepède (1788), but that publication and name was suppressed by ICZN (2005), shifting the valid authorship of the same name to Bonnaterre (1789). Several other nominal taxa (and named nomen novum variants thereof) have been described that have been 


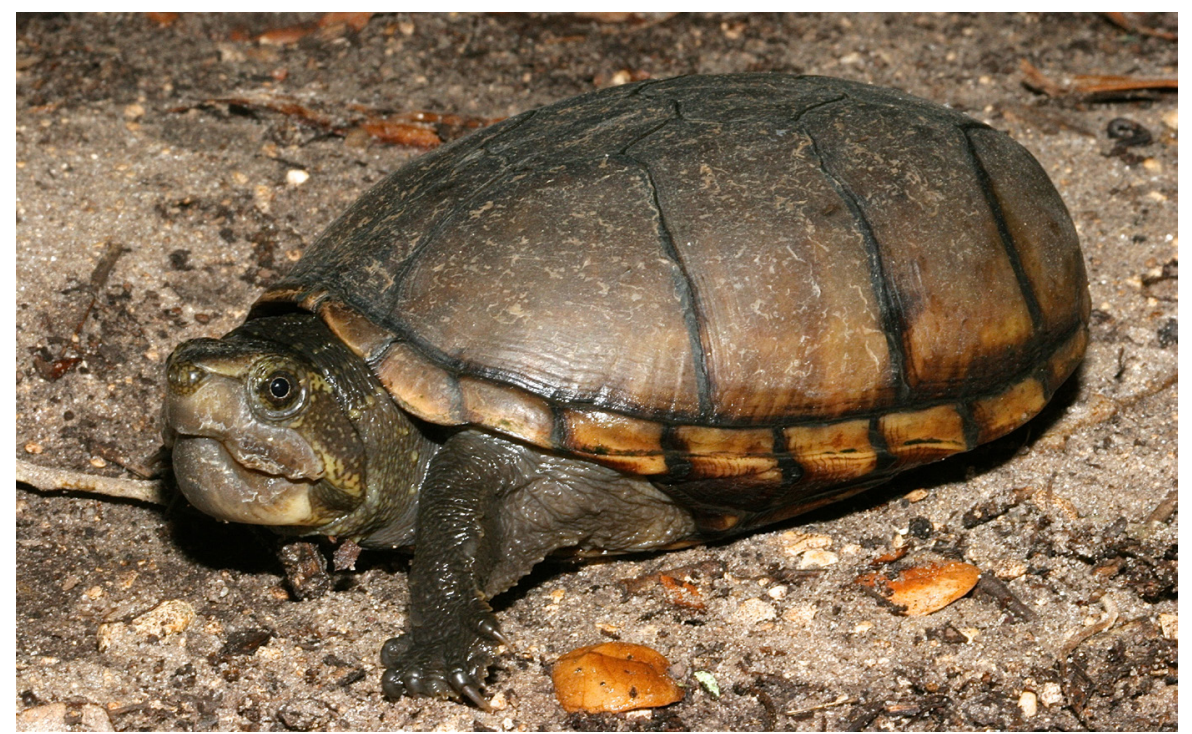

Figure 1. Kinosternon subrubrum subrubrum, Apalachicola National Forest, Florida, USA. Photo by R.D. Bartlett.

synonymized with $K$. subrubrum: Testudo pensilvanica Gmelin (1789), Kinosternon doubledayii Gray (1844), Kinosternonoblongum Gray (1844), Kinosternon punctatum Gray (1856), and Swanka fasciata Gray (1869) (Iverson 1977a, TTWG 2014). Three subspecies of K. subrubrum have been recognized for a long time: $K$. s. subrubrum, $K$. s. steindachneri (Siebenrock 1906), and K. s. hippocrepis (Gray 1856).

Analysis of mitochondrial DNA of $K$. subrubrum has provided general conformity to the geographic distributions of the three subspecies (Walker et al. 1998), but further mtDNA analysis of the species by Iverson et al. (2013) indicated that K. s. steindachneri was more closely related to $K$.baurii than to $K$. subrubrum, suggesting that steindachneri deserves species status. However, Spinks et al. (2014) recommended retention of steindachneri as a subspecies of subrubrum.

Kinosternon s. steindachneri is different from both of the other subspecies in having a relatively reduced plastron and bridge (Meshaka and Gibbons 2006). Extensive morphological analysis of fossils and extant species by Bourque and Schubert (2015) and Bourque (2016) has led to

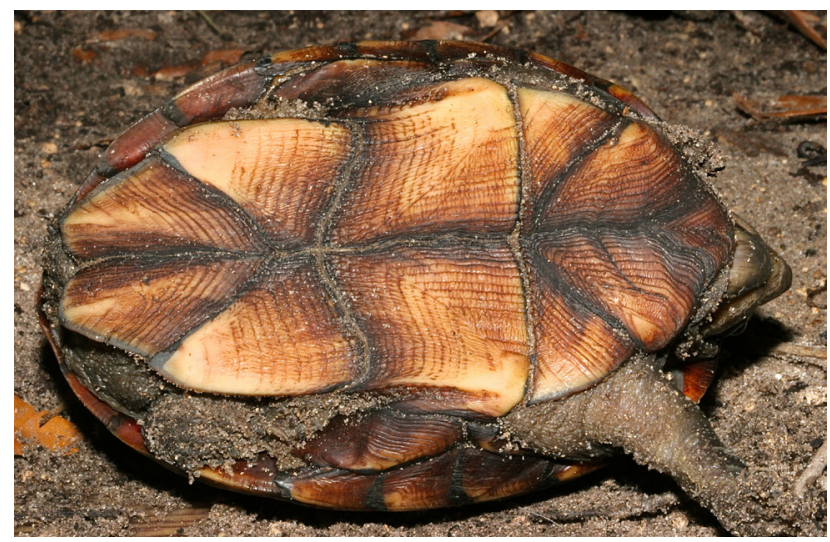

Figure 2. Kinosternon subrubrum subrubrum, Apalachicola National Forest, Florida, USA. Photo by R.D. Bartlett. the recommendation that $K$. s. steindachneri be considered a distinct species. This recommendation has been followed by Powell et al. (2016), and in their most recent checklist, TTWG (2017) also agreed, and listed K. steindachneri as a distinct species. However, we continue to treat steindachneri as a subspecies for the purposes of this account, pending further analysis and, hopefully, resolution of the issue.

Description. - Kinosternon subrubrum is a small, smooth-domed turtle. Adults of both sexes reach maturity at around 70-80 $\mathrm{mm}$ in carapace length (CL). Mean CL of adults is approximately $85 \mathrm{~mm}$, with the largest individuals normally attaining lengths less than $120 \mathrm{~mm}$, with no sexual size dimorphism (Gibbons and Lovich 1990). The color of the carapace of adults ranges from dark brown to black but is occasionally olive, and without lighter-colored carapacial stripes. Kinosternon subrubrum can be difficult to distinguish from the Striped Mud Turtle (K. baurii) in the panhandle of Florida, Georgia, the Carolinas, and Virginia because of the frequent absence of carapacial stripes in K. baurii in these areas (Duever 1972; Lamb 1983; Lamb and Lovich 1990; Ewert et al. 2004). However, $K$. baurii generally retains

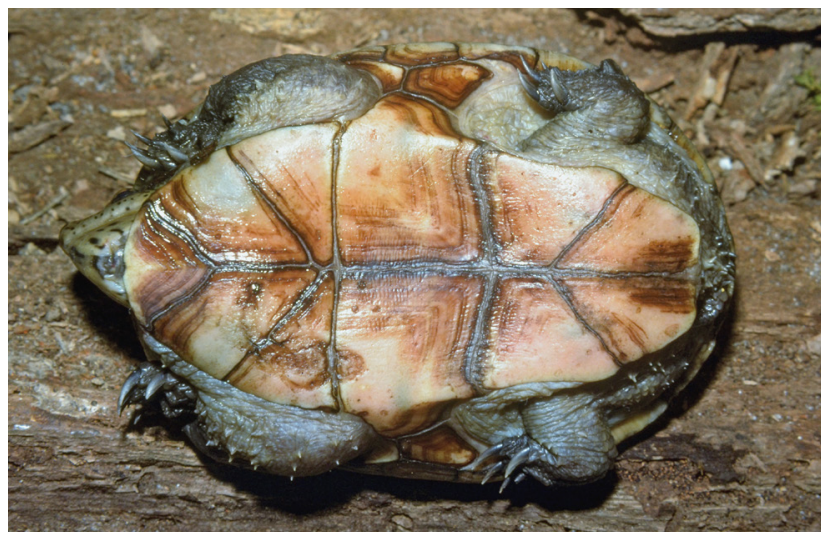

Figure 3. Kinosternon subrubrum steindachneri, Monroe County, Florida, USA. Note the reduced plastron. Photo by J.B. Iverson. 
distinct head stripes throughout its range, in contrast to $K$. s. subrubrum that lacks them. The carapace of hatchlings (21-26 mm CL) is black.

The carapace of $K$. subrubrum is oval in dorsal view, smooth, and rounded on the sides. It has 11 marginal scutes on each side, and the 10th marginal extends further dorsally than the others. The first vertebral scute is longer than wide and does not contact the 2nd marginal scute. The other vertebrals (2-5) are usually wider than long.

The plastron of adults is dark brown or a drab yellow. Because the plastron of subadult and adult K. subrubrum has a double hinge, complete closure of the shell is possible in some individuals. The anterior hinge is between the epiplastra and hyoplastra (the entoplastron is absent), and the posterior hinge is between the hypoplastra and xiphiplastra. The plastral formula is anal $>$ abdominal $>$ humeral $>$ femoral $><$ gular $>$ pectoral (Ernst and Barbour 1989); however, this formula is highly variable in species to which it has been applied (Lovich and Ernst 1989; Lovich et al. 1991; Ernst et al. 1997b).

The feet are webbed and the limbs are dark with no markings. The head is dark brown to black, but subspecific variation occurs in head markings. The Eastern Mud Turtle (K. s. subrubrum) and the Florida Mud Turtle (K. s. steindachneri) have plain heads or dull yellow mottling, whereas the Mississippi Mud Turtle (K. s. hippocrepis)

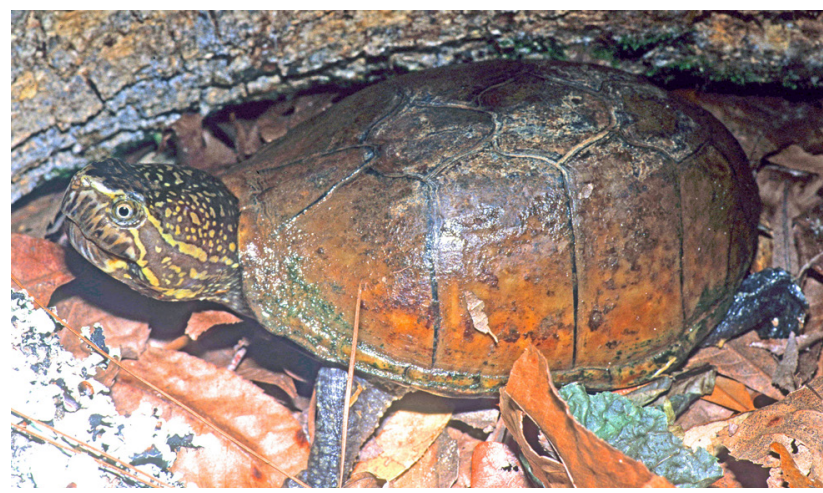

Figure 4. Kinosternon subrubrum hippocrepis, Mississippi or Louisiana, USA. Photo by R.D. Bartlett.

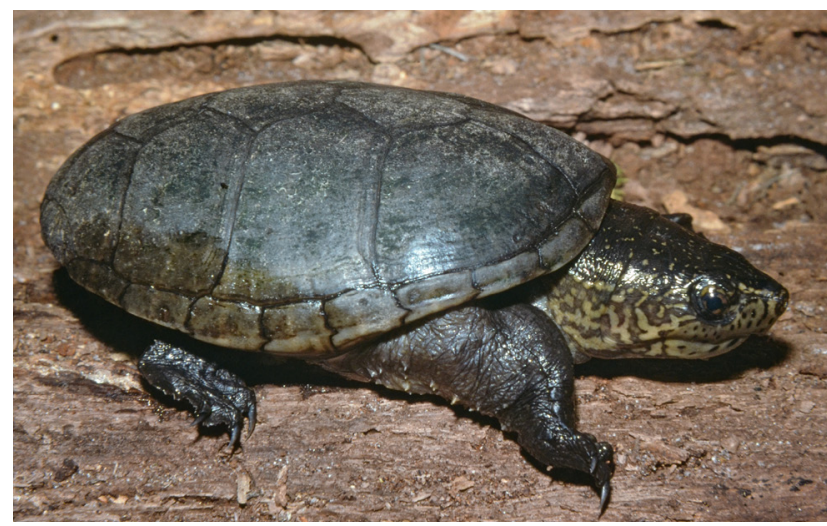

Figure 5. Kinosternon subrubrum steindachneri, Monroe County, Florida, USA. Photo by J.B. Iverson. has two yellow stripes on each side of the head. Differing from adults, hatchlings may have bright yellow, orange, or red plastrons with some dark markings. In this regard, the red color of the plastron among some juveniles gave rise to the specific name of subrubrum. Two faint light stripes are on the head and neck of $K$. s. hippocrepis, and a broad light postorbital stripe may be found on hatchlings of $K$. s. steindachneri (Ernst and Lovich 2009).

The upper jaw is mildly hooked with a slightly protruding snout. Sexual dimorphism is apparent in the head, tail, and hind limbs. Males have a larger head size, a keratinized claw-like tip at the end of the tail, and a longer tail length

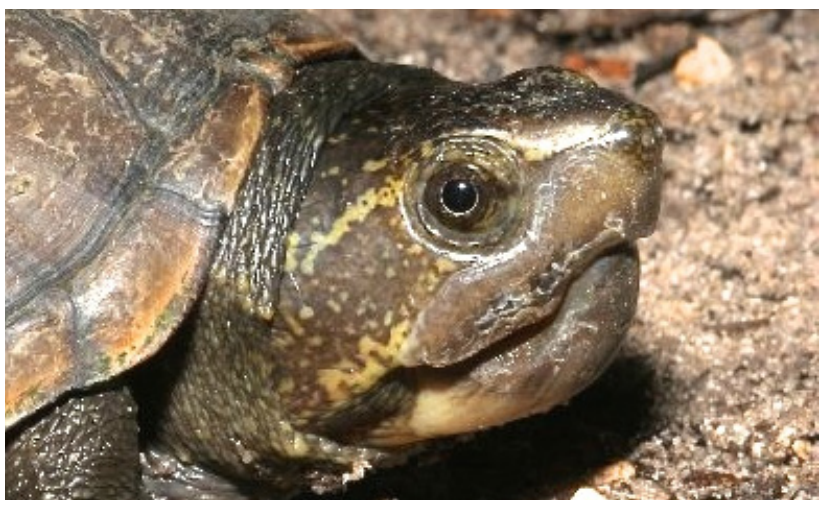

Figure 6. Kinosternon subrubrum subrubrum, Apalachicola National Forest, Florida, USA. Photo by R.D. Bartlett.

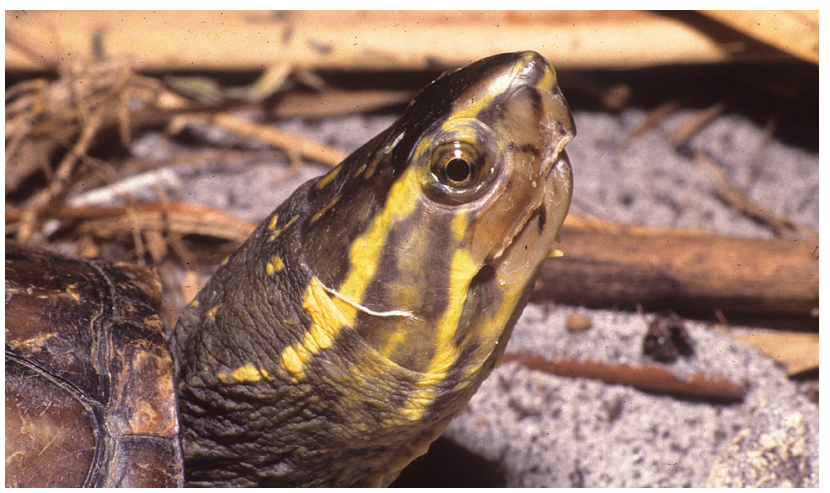

Figure 7. Kinosternon subrubrum hippocrepis, Mississippi or Louisiana, USA. Photo by R.D. Bartlett.

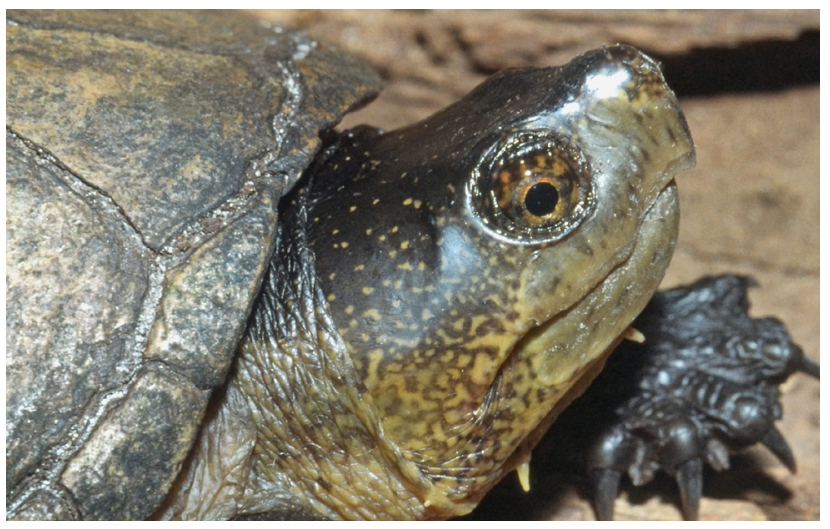

Figure 8. Kinosternon subrubrum steindachneri, Levy County, Florida, USA. Photo by J.B. Iverson. 


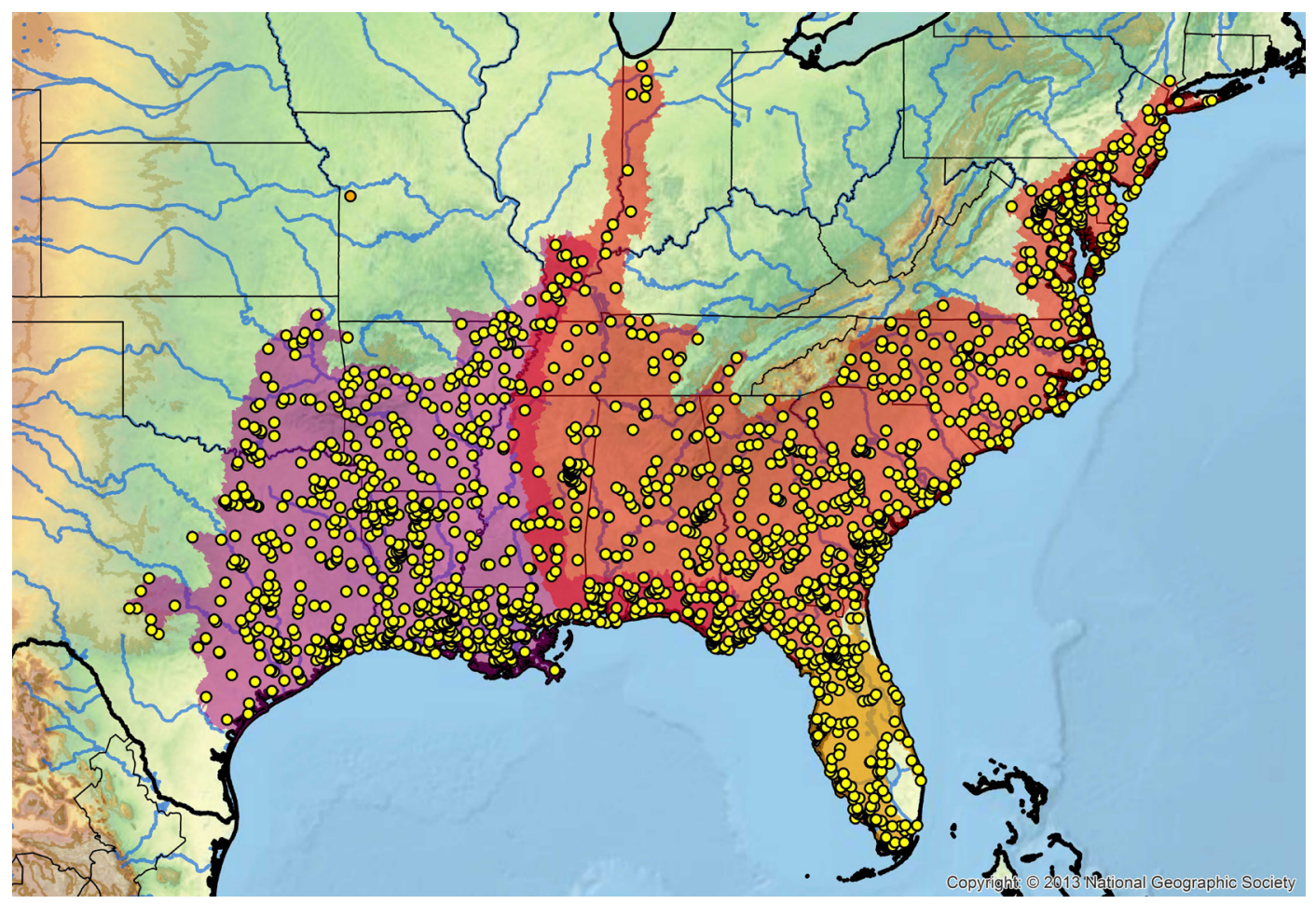

Figure 9. Historic distribution of Kinosternon subrubrum in eastern USA. Yellow dots = museum and literature occurrence records of native populations based on Iverson (1992), plus more recent and authors' data; orange dot = possibly introduced population; red shading $=$ projected historic distribution of K. s. subrubrum; purple shading $=$ K. s. hippocrepis; orange shading $=$ K. s. steindachneri; overlap $=$ intergrades. Distribution based on GIS-defined level 10 HUCs (hydrologic unit compartments) constructed around verified localities and then adding HUCs that connect known point localities in the same watershed or physiographic region, and similar habitats and elevations as verified HUCs (Buhlmann et al. 2009; TTWG 2014), and adjusted based on authors' subsequent data.

than females. Two patches of enlarged scales are also present on the inner side of each hind limb of males, but absent in females.

Distribution. - Kinosternon subrubrum is a North American species of generally southern latitudes in the United States. Its geographic distribution is within the eastern and central United States (Powell et al. 2016) and the northern distributional limit overlaps the southern terminus of the Wisconsin glaciation (Craig et al. 1980). The species ranges southerly from southeastern New York (Craig et al. 1980; Iverson 1986; Klemens 1990, 1993) across the Atlantic

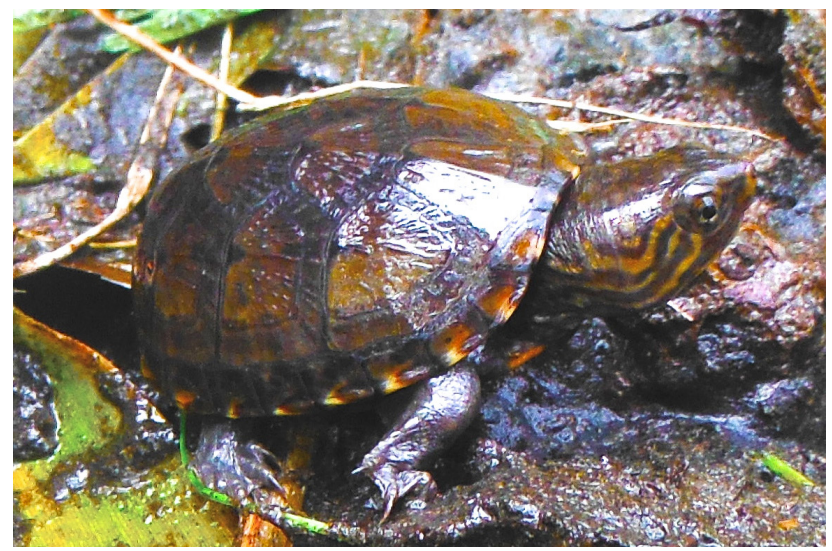

Figure 10. Kinosternon subrubrum subrubrum, small juvenile in the wild, Wallops Island, Virginia, USA. Photo by P.R. Delis.
Coastal states and Piedmont through peninsular Florida (Ernst and Lovich 2009). Its geographic range extends westward along the Gulf Coastal Plain to eastern Texas and Oklahoma, with a northward extension in the range following the Mississippi and Ohio River valleys to southwestern Indiana, southern Illinois, and southeastern Missouri (Ernst and Lovich 2009). Possibly disjunct records occur from northwestern Indiana (Grant 1935; Stille 1947; Minton 1972) and northwestern Missouri (Anderson 1965), although the latter was interpreted as an introduction (Johnson 1987).

The nominate subspecies, $K$. s. subrubrum, occurs throughout the northeastern and southeastern coastal plain, south into northern Florida, west towards the Mississippi River, and north into the Midwest into Illinois and Indiana (Ernst and Lovich 2009).

Kinosternon s. hippocrepis is the westernmost form that occurs along the Mississippi Valley north to southeastern Missouri, western Kentucky, and southern Illinois, and westward to central Oklahoma and eastern Texas (Ernst and Lovich 2009). A broad zone of intergradation exists along its east extension where it contacts $K$. s. subrubrum from southern Illinois south to the coasts of Mississippi and Alabama (Powell et al. 2016), and along the Florida panhandle (Carr 1940; Powell et al. 2016).

The geographic range of the Florida endemic, $K . s$. steindachneri, includes only peninsular Florida south of the 
Suwannee River drainage and Jacksonville to the southern tip of the state, but not the Florida Keys (Meshaka and Gibbons 2006). In northern Florida, K. s. steindachneri intergrades narrowly with K. s. subrubrum (Powell et al. 2016).

Habitat and Ecology. - Kinosternon subrubrum is a semi-aquatic turtle whose terrestrial habits vary in degree among the subspecies. Aquatic habitats of the species tend to be shallow and slow moving or lentic freshwater systems, but it also has been reported to inhabit brackish marshes (Ernst and Lovich 2009) and is a successful colonizer of barrier islands (Gibbons and Coker 1978). This turtle appears to avoid major rivers, streams, and spring runs (Gibbons 1983; Huestis and Meylan 2004). In Virginia, the aforementioned lentic habitats are occupied, and especially those with aquatic or emergent macrophytes and a soft substrate (Mitchell 1994). Kinosternon s. subrubrum was reported from coastal plain freshwater marshes in Maryland subject to tide cycles (Cordero and Swarth 2010). In North Carolina, the species has also been found in association with sandy-bottomed creeks, streams, farm ponds, vernal woodland pools, meadows and pastures, swamps, canals, and drainage ditches (Palmer and Braswell 1995). Ditches in managed forests in eastern North Carolina proved to be acceptable habitat for $K$. subrubrum, and their occupancy was unaffected by neither time since maintenance, which ranged 3-17 yrs, nor by landscape metrics of nearby forest and wetlands (Homyack et al. 2016). In some cases, golf course ponds could be more suitable for this species than farm ponds (Failey et al. 2007). In turn, farm ponds with high nitrite/nitrate concentrations in association with cattle were inhabited by individuals that were significantly smaller and produced narrower eggs than those that did not have cattle grazing (Lindsay and Dorcas 2001). In South Carolina, individuals were found in association with older beaver ponds (Russell et al. 1999). In Alabama, K. subrubrum was least likely to be found in free-flowing creeks and rivers (Mount 1965), and in Alabama farm ponds this species did not venture more than $5 \mathrm{~m}$ from shore and no deeper than 1 $\mathrm{m}$ (Scott 1976). An affinity for shallow, heavily-vegetated habitat, K. subrubrum in two southeastern Oklahoma rivers (Riedle et al. 2009) and an East Texas wetland (Riedle et al. 2015) were seldom captured with two Sternotherus species, which were associated with greater water depth and flow. In a lake in Louisiana, K. subrubrum was captured in abundance in the vicinity of Lotus beds at water depths ranging 0.9-1.2 m (Cagle and Chaney 1950). Individuals were also seen foraging in many shallow rivulets and streams in water that did not cover their carapaces (Cagle and Chaney 1950).

In Florida, K. s. subrubrum and K. s. steindachneri occur in small streams, drainage ditches, and ponds (Carr 1940); however, the Florida form also inhabits sloughs and marshes (Carr 1940) and canals (Duellman and Schwartz
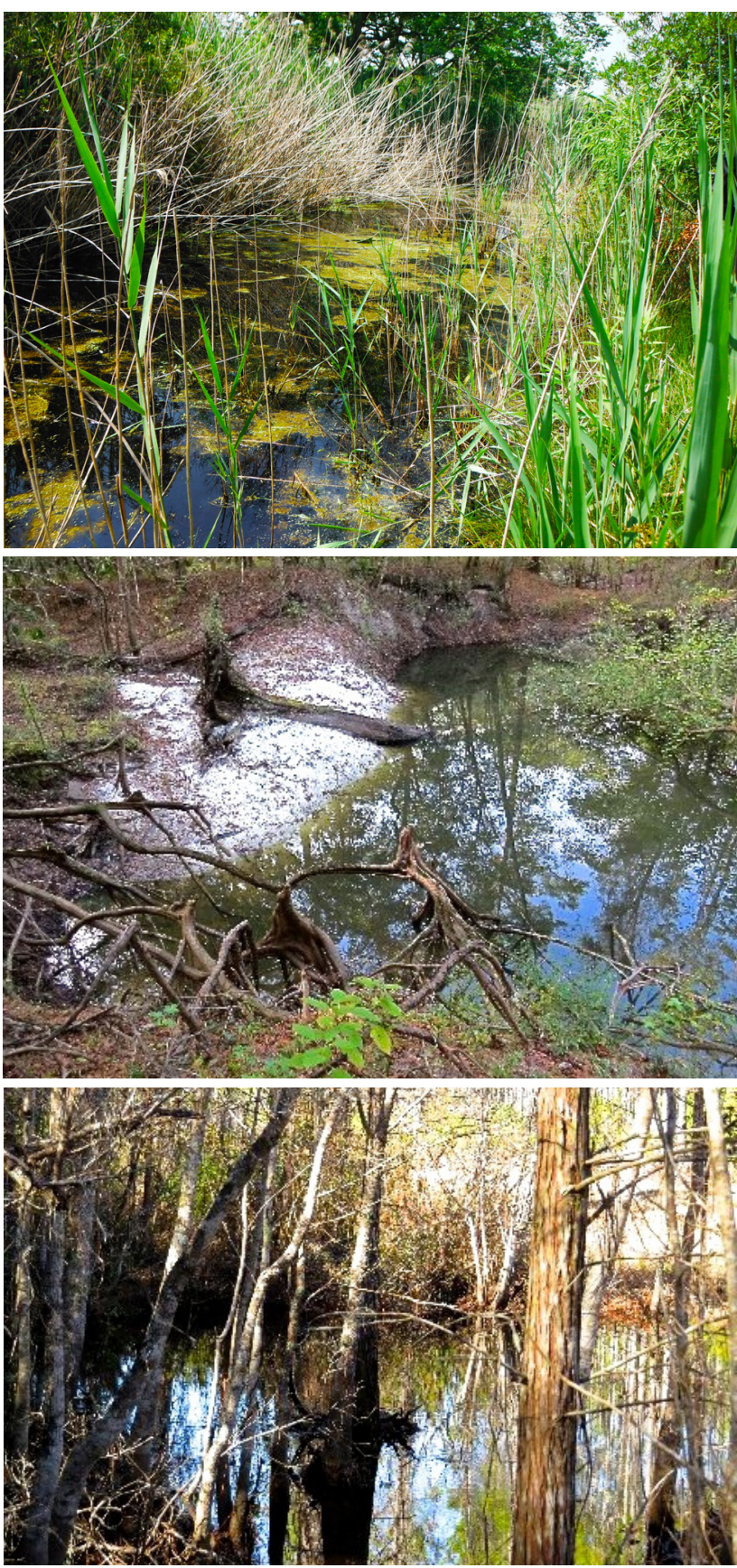

Figure 11. Habitat of Kinosternon subrubrum.Top: Wallops Island, Virginia. Photo by P.R. Delis. Middle and Bottom: Apalachicola National Forest, Florida, USA. Photos by R.D. Bartlett.

1958). This subspecies can occupy aquatic habitats that fluctuate widely in $\mathrm{pH}$ on a daily basis (Ernst et al. 1972). In a central Florida lake, K. s. steindachneri was most commonly found in vegetated littoral zones with thin-stalked emergent vegetation (Bancroft et al. 1983). More than $95 \%$ of all individuals in the lake were found in water that was < $1.6 \mathrm{~m}$ in depth with a sandy substrate and thick vegetative cover, especially Potamogeton illinoensis (Bancroft et al. 1983). In west-central Florida, K. s. steindachneri was the only kinosternid turtle found in a shallow basin marshsandy upland association (Enge and Wood 2001), whereas 
in the marsh and prairie of the Everglades, it was replaced in abundance by K. baurii (Duellman and Schwartz 1958; Meshaka et al. 2000).

The activity season of $K$. subrubrum varies geographically. Seasonal activity is shortest in northern populations and longest in the South (Ernst and Lovich 2009): April-November in New York (Nichols 1947), January-November in North Carolina (Palmer and Braswell 1994), April-October in Oklahoma (Mahmoud 1969), and year-round in Alabama (Mount 1975) and Florida (Bancroft et al. 1983; Ernst and Lovich 2009). Seasonal activity of $K$. s. steindachneri in central Florida peaked in early summer and fall (Bancroft et al. 1983). Iverson (1979), having reported that only 2 of $62 \mathrm{~K}$. subrubrum that he examined from north and central Florida were collected during 15 June-15 August, suggested the occurrence of a break in summer activity in that region.

Kinosternon subrubrum is active at night and during the day. In northern Virginia, most captures of K. s. subrubrum occurred during 0700-0830 hrs (Ernst et al. 1997a). In Alabama, K. subrubrum is active more often at night than during the day (Mount 1975), and in central Florida, K. s. steindachneri was captured by day and night with no apparent seasonal component to its diel activity pattern (Bancroft etal. 1983). In the summer, activity peaks during 0500-0800 hrs and 1900-2200 hrs for both K. s. hippocrepis in Oklahoma (Mahmoud 1969) and K. s. steindachneri in Florida (Ernst and Lovich 2009).

Aquatic movements are generally short, and home ranges are small in K. subrubrum. Average daily movements in New York were $5.6 \mathrm{~m}$ for males and $4.2 \mathrm{~m}$ for females during the aquatic activity season, and 5.3 and $4.0 \mathrm{~m}$, respectively, during terrestrial searching for hibernation sites (LareseCasanova 1999). First-last capture distances in less than 100 days averaged $<50 \mathrm{~m}$ for $K$. s. hippocrepis in Oklahoma (Mahmoud 1969). In central Florida, the average distance moved by K. s. steindachneri between captures was 32.8 $\mathrm{m}$ (Bancroft et al. 1983). In Oklahoma, the average home range of K. s. hippocrepis was 0.05 ha (Mahmoud 1969). Contrary to these patterns, aquatic movement data yielded maximum distance movements $>1000 \mathrm{~m}$ and mean home range sizes of 18.6 and 16.3 ha for two different years in a Maryland population of K. s. subrubrum (Cordero et al. 2012a). Kinosternon subrubrum can be highly terrestrial in its habits.

Terrestrial movements can be initiated by nesting (Burke et al. 1994) or drought (Gibbons 1983; Ernst and Lovich 2009). In South Carolina, individuals temporarily left a drying environment, burrowed solitarily up to $600 \mathrm{~m}$ away, and returned later; this was interpreted to be an adaptation to a fluctuating environment, whereby selection works against aggregation in the drying pond where a population could be devastated by a predator (Bennett et al. 1977). In other drought conditions, the number of emigrating individuals was within the mean reported for non-drought years (Gibbons et al. 1983). Terrestrially moving turtles can be at risk from fire; however, K. subrubrum will burrow into the substrate to avoid fire (Folk and Bales 1982).

Although some individuals will overwinter in underwater retreats, others will make overland movements to hibernate away from water (Larese-Casanova 1999; Buhlmann and Gibbons 2001; Harden and Dorcas 2008; Cordero et al. 2012 b), and the overwintering sites can be far from aquatic habitat. For example, in Maryland, turtles overwintered 55-224 $\mathrm{m}$ from the edge of the wetland (Cordero et al. 2012b), and in South Carolina distances traveled ranged to $600 \mathrm{~m}$ (Bennett et al. 1970). In southwestern Georgia turtles overwintered at an average of $72 \mathrm{~m}$ from a wetland for an average of 107 days (Steen et al. 2007).

Winter burrow depth varies geographically. In Illinois, turtles burrowed 20-40 cm or more deep (Skorepa and Ozment 1968); in New York, depths averaged $25 \mathrm{~cm}$ (LareseCasanova 1999). Burrow depths in Maryland ranging 7.0-25 $\mathrm{cm}$ (mean burrow depths for two years $=12.1$ and $13.2 \mathrm{~cm}$ ) were presumed to be in response to freezing temperatures (Cordero et al. 2012b). In Oklahoma, burrow depths were 10-15 cm (Mahmoud 1969). In South Carolina, individuals burrowed 2-11 cm below the surface, and movement from burrows did not commence until maximum air temperature exceeded $21{ }^{\circ} \mathrm{C}$ (Bennett 1972).

The length of hibernation is positively correlated with latitude. Hibernation lasted an average of 211 and 220 days over two winters in southeastern New York (Larese-Casanova 1999), although Nichols (1947) reported a hibernation period of 151 days on Long Island. Gibbons (1970) and Bennett (1972) reported a hibernation period of about 120 days in South Carolina, Mahmoud (1969) recorded 100 days in Oklahoma, and Scott (1976) observed 70 and 86 days in Alabama.

In southwestern Georgia, turtles preferred extensive leaf and pine litter and lesser canopy cover for overwintering sites than for other temporary refuges or random sites (Steen et al. 2007). Habitat quality was found, in turn, to depend on timing of prescribed fires that would best suppress oaks if conducted in the spring and summer (Steen et al. 2007). In a disturbed site in North Carolina, individuals likewise preferred physical components of leaf and pine litter, herbaceous vegetation, fallen woody debris and canopy cover associated with overwintering sites (Harden et al. 2009). Consequently, adults inhabiting an artificial pond avoided human-altered terrestrial habitat on their way to overwintering sites (Harden et al. 2009).

Nesting activity was associated with rain in South Carolina (Burke et al.1994) as were terrestrial movements in Virginia (Mitchell 1994). In North Carolina, most terrestrial activity occurred during morning and late afternoon (Palmer 
and Braswell 1995). Overland distances could be long: up to $600 \mathrm{~m}$ by K. s. subrubrum in South Carolina, which were traversed a few meters at a time (Bennett et al. 1970). The number of days it takes to complete overland movements can likewise be long in duration, up to 142 days (Bennett et al. 1970) and 170 days (Buhlmann and Gibbons 2001) in South Carolina. Individuals remain under cover when they rest between movements (Richmond 1945; Skorepa and Ozment 1968; Gibbons 1970; Mount 1975). Dietz and Jackson (1979) and Elsey et al. (2013) documented their use of alligator nests for nest sites.

Although not exclusively aquatic, $K$. s. steindachneri is the least terrestrial of the three subspecies. In southern Florida,individuals have been collected on roads (Duellman and Schwartz 1958), even if rarely (Meshaka, Gibbons, pers. obs.); however, it is very aquatic in its habits (Carr 1940), having never been seen on land during a three-year study in central Florida (Bancroft et al. 1983). In this connection, the reduced plastron and reduced bridge, which are the primary differences between K.s.steindachneri and the other Florida subspecies, are suggestive of a more aquatic existence.

Growth rates and sexual maturity vary among populations of K. subrubrum. Both sexes of K. s. subrubrum mature in 4-6 yrs in South Carolina (Gibbons 1983) and 9 years in New York (Larese-Casanova 1999), whereas female K. s. hippocrepis in Arkansas are mature at 6-8 yrs (Iverson 1979). Sexual maturity in mixed subspecies from Florida was reached earlier in males (4-5 yrs) than in females (6-8 yrs) (Ernst et al. 1973). Sexual maturity is reached at 70-80 mm CL by both sexes of K. s. subrubrum in South Carolina (Gibbons 1983). Maturity in Arkansas females is at 80-85 mm CL (Iverson 1979). Ernst et al. (1973) reported maturity in Florida in males at 53-60 mm PL and in females at 66-75 mm PL (estimated CL from Iverson 1991, 67-76 mm and 76-87 mm, respectively)..

Body size dimorphism varies among the subspecies of K. subrubrum. Little body size dimorphism is apparent in K.s.subrubrum (Lovich and Lamb 1995). Carapace lengths of this subspecies are similar between the sexes in Virginia (Mitchell 1994), North Carolina (Palmer and Braswell 1995), and South Carolina (Gibbons and Lovich 1990); however, plastron lengths are smaller in males (Gibbons and Lovich 1990). Body size dimorphism is femaledominated in K. s. hippocrepis and is male-dominated in K. s. steindachneri (Lovich and Lamb 1995). In a central Florida population of K. s. steindachneri, mean adult body size of males (101.2 mm CL; $\mathrm{n}=53$ ) was significantly different than that of females (93.8 mm CL; $n=29$; Bancroft et al.1983). Among individuals examined from throughout Florida, the largest male (114.3 mm CL) was larger than the largest female (106 mm CL) (Iverson 1979), and the largest males averaged larger than the largest females in peninsular Florida (Ernst et al. 1973). The variability in body size dimorphism was considered to be a biologically meaningful difference among these three subspecies (Meshaka and Gibbons 2006).

The gonadal cycles of $K$. subrubrum are known only from a few areas. The testis of K.s. hippocrepis in the central United States is at its maximum size June-August and is smallest in size during September-December (Mahmoud and Klicka 1972). In Arkansas, follicular growth begins in late summer or early fall and increases rapidly the following spring (Iverson 1979).

Copulation has been described for K. s. hippocrepis. Mahmoud (1967) noted an initial approach by the male to the tail of the female, which was then followed by his movement alongside her. There, the male nudges the bridge area of her plastron, presumably to make contact with the musk glands. If the female continues to be receptive, the male then mounts from behind and above, and while in copula, bites her head and carapace.

Kinosternon subrubrum mates in the spring and early summer. Mating takes place during March-May, with southern populations breeding earliest (Ernst and Lovich 2009). Nesting seasons vary geographically and are shorter in northern populations (Iverson 1979): March-September in Virginia(Richmond 1945), March-June in Virginia (Mitchell 1994; Ernst et al. 2001), April-July in Arkansas (Iverson 1979), January-July in Louisiana (Dundee and Rossman 1989), and October-June in north Florida (Iverson 1977b). The frequency of nesting is highest in the summer throughout most of its geographic range (Gibbons 1983).

The eggs of K. s. subrubrum are brittle-shelled, with a granular appearance (Congdon and Gibbons 1985). Eggs average about 25-27 $\mathrm{mm}$ in length, 15-17 $\mathrm{mm}$ in width, and about $4 \mathrm{~g}$ (Carr 1940, Iverson 1979, Congdon and Gibbons 1985, Dundee and Rossman 1989, Mitchell 1994, Palmer and Braswell 1995, and Wilkinson and Gibbons 2005). There may be a weak pattern of smaller eggs at higher latitudes (Iverson 1979).

Clutch characteristics of $K$. subrubrum are variable. Clutch size in this species varies geographically, seasonally, and as a function of female size (Iverson 1979; Gibbons 1983). Throughout the geographic range of the species, clutch size varies from 1-8 eggs (Gibbons 1983) with larger clutches being more common in northern populations. Modal clutch size is 2-3 eggs (Gibbons 1983).Across its geographic range, K. subrubrum can lay up to four clutches annually (Iverson 1979; Gibbons 1983). In South Carolina, clutch frequency was shown to vary among individuals and among years (Frazer et al. 1991). In response to drought, the percentage of females that produced more than one clutch was lower than those of pre-drought conditions (Gibbons et al. 1983). Clutch characteristics among multiple clutches were shown to vary within annual reproductive cycles (Wilkinson and Gibbons 2005). 
Table 1. Presence of Kinosternon subrubrum in major federally protected areas found within its natural distribution: National Parks (all), National Preserves (all), National Forests (> 30,000 ha), and National Wildlife Refuges (>20,000 ha, except in smaller states such as Delaware). The distribution of K. subrubrum spans 21 states across the southeastern United States, including Alabama, Arkansas, Delaware, Florida, Georgia, Illinois, Indiana*, Kentucky**, Louisiana, Maryland, Mississippi, Missouri, New Jersey, New York*, North Carolina, Oklahoma, Pennsylvania*, South Carolina, Tennessee, Texas, and Virginia. Species presence or absence in a protected area was determined from federally protected area websites (US Forest Service, US Fish and Wildlife, National Park Service), primary literature sources, range map, published conservation plans, and various state field guides. $*=$ State listed endangered species. $* *=$ State listed species of greatest conservation need. $\mathrm{X}=$ presence confirmed from source(s); $\mathrm{L}=$ Presence determined to be highly likely based on source(s) and/or range map; $\mathrm{P}=$ Presence unknown, but determined to be probable based on source(s) and/or range map. ${ }^{\wedge}=$ Only National Recreation Area on this list. ${ }^{\wedge}=$ Only National Wildlife Research Refuge on this list. ${ }^{\wedge \wedge}=$ Only National Reserve on this list.

Size (ha) Presence Source

\begin{tabular}{|c|c|c|c|}
\hline \multicolumn{4}{|l|}{ Alabama } \\
\hline Little River Canyon National Preserve & 6,187 & $\mathrm{X}$ & National Park Service \\
\hline Talladega National Forest & 158,866 & $\mathrm{X}$ & US Forest Service \\
\hline William B. Bankhead National Forest & 73,300 & $\mathrm{X}$ & US Forest Service \\
\hline Conecuh National Forest & 33,900 & $\mathrm{X}$ & US Forest Service \\
\hline \multicolumn{4}{|l|}{ Arkansas } \\
\hline Hot Springs National Park & 2,250 & $\mathrm{~L}$ & Robert and Irwin 2012; Trauth et al. 2004 \\
\hline Ouachita National Forest & 722,100 & $\mathrm{X}$ & Trauth et al. 2004 \\
\hline Ozark-St. Francis National Forest & 469,400 & $\mathrm{X}$ & Trauth et al. 2004 \\
\hline Dale Bumpers White River National Wildlife Refuge & 64,335 & $\mathrm{X}$ & US Fish and Wildlife \\
\hline Cache River National Wildlife Refuge & 26,776 & $\mathrm{~L}$ & Roberts and Irwin 2012; Trauth et al. 2004 \\
\hline Felsenthal National Wildlife Refuge & 26,265 & $\mathrm{~L}$ & Roberts and Irwin 2012; Trauth et al. 2004 \\
\hline \multicolumn{4}{|l|}{ Delaware } \\
\hline Bombay Hook National Wildlife Refuge & 6,466 & $\mathrm{X}$ & US Fish and Wildlife \\
\hline Prime Hook National Wildlife Refuge & 4,000 & $\mathrm{X}$ & Coppola 2013 \\
\hline \multicolumn{4}{|l|}{ Florida } \\
\hline Everglades National Park & 610,484 & $\mathrm{X}$ & $\begin{array}{l}\text { Duellman and Schwartz 1958; Meshaka et al. 2000; Meshaka and } \\
\text { Gibbons 2006; Meshaka and Layne 2015; Rice et al. } 2004\end{array}$ \\
\hline Biscayne National Park & 69,999 & $\mathrm{P}$ & $\begin{array}{l}\text { National Park Service (undetected, but K. bauri confirmed); Krysko et al. } \\
2010 \text { (unidentified Kinosternon spp.); Rice et al. } 2007 \text { (undetected) }\end{array}$ \\
\hline Big Cypress National Preserve & 291,603 & $\mathrm{X}$ & National Park Service; Rice et al. 2005 (undetected) \\
\hline Apalachicola National Forest & 233,100 & $\mathrm{X}$ & Krysko et al. 2011; Means 1976a \\
\hline Ocala National Forest & 174,196 & $\mathrm{X}$ & Krysko et al. 2011; Means 1976b \\
\hline Osceola National Forest & 77,267 & $\mathrm{X}$ & Krysko et al. 2011; Means 1976c \\
\hline Key West National Wildlife Refuge & 84,299 & $\mathrm{P}$ & Morkill 2009 (undetected, but K. bauri confirmed) \\
\hline Arthur R. Marshall Loxahatchee National Wildlife Refuge & 58,256 & $\mathrm{X}$ & Musaus 2000 \\
\hline Merritt Island National Wildlife Refuge & 56,328 & $\mathrm{P}$ & US Fish and Wildlife (undetected, but $K$. bauri confirmed) \\
\hline Great White Heron National Wildlife Refuge & 47,640 & $\mathrm{P}$ & Morkill 2009 (undetected, but K. bauri confirmed) \\
\hline National Key Deer Refuge & 34,327 & $\mathrm{P}$ & Morkill 2009 (undetected, but K. bauri confirmed) \\
\hline Saint Marks National Wildlife Refuge & 28,003 & $\mathrm{X}$ & US Fish and Wildlife \\
\hline Lower Suwannee National Wildlife Refuge & 20,651 & $\mathrm{X}$ & Gunzburger et al. 2005 \\
\hline \multicolumn{4}{|l|}{ Georgia } \\
\hline Chattahoochee-Oconee National Forest & 350,600 & $\mathrm{X}$ & Jensen et al. 2008 \\
\hline Okefenokee National Wildlife Refuge & 162,647 & $\mathrm{X}$ & Constantino 2006 \\
\hline \multicolumn{4}{|l|}{ Illinois } \\
\hline Shawnee National Forest & 107,400 & $\mathrm{X}$ & Smith 1961 \\
\hline \multicolumn{4}{|l|}{ Kentucky** } \\
\hline Mammoth Cave National Park & 21,380 & $\mathrm{X}$ & Hibbard 1936 \\
\hline Land Between the Lakes National Recreation Area ${ }^{\wedge}$ & 68,800 & $\mathrm{X}$ & Kentucky’s Comprehensive Wildlife Conservation Strategy 2013 \\
\hline \multicolumn{4}{|l|}{ Louisiana } \\
\hline Kisatchie National Forest & 244,000 & $\mathrm{~L}$ & Range map \\
\hline Sabine National Wildlife Refuge & 50,905 & $\mathrm{X}$ & Valentine et al. 1972 \\
\hline Tensas River National Wildlife Refuge & 29,611 & $\mathrm{X}$ & Purkey 2009 \\
\hline \multicolumn{4}{|l|}{ Maryland } \\
\hline Chesapeake Marshlands National Wildlife Refuge Complex & $x \quad 13,767$ & $\mathrm{~L}$ & Range map \\
\hline Patuxent National Wildlife Research Refuge ${ }^{\wedge \wedge}$ & 5,200 & $\mathrm{X}$ & Knudsen 2013 \\
\hline \multicolumn{4}{|l|}{ Mississippi } \\
\hline De Soto National Forest & 209,900 & $\mathrm{X}$ & Smith and List 1955 \\
\hline Homochitto National Forest & 77,600 & $\mathrm{~L}$ & Range map \\
\hline Bienville National Forest & 72,200 & $\mathrm{~L}$ & Range map \\
\hline Holly Springs National Forest & 62,900 & $\mathrm{~L}$ & Range map \\
\hline \multicolumn{4}{|l|}{ New Jersey } \\
\hline Edwin B. Forsythe National Wildlife Refuge & 16,200 & $\mathrm{P}$ & Range map; Atzert 2004 (undetected) \\
\hline New Jersey Pinelands National Reserve $\mathrm{A}^{\wedge \wedge}$ & 471,064 & $\mathrm{X}$ & National Park Service; Pinelands Preservation Alliance \\
\hline \multicolumn{4}{|l|}{ New York* } \\
\hline Long Island National Wildlife Refuge Complex & 2,606 & $\mathrm{X}$ & Long 2006; Mann-Klager and Parris 1993 \\
\hline \multicolumn{4}{|l|}{ North Carolina } \\
\hline Nantahala National Forest & 215,000 & $\mathrm{~L}$ & Range map \\
\hline Pisgah National Forest & 207,500 & $\mathrm{X}$ & Weeks 2008 \\
\hline
\end{tabular}




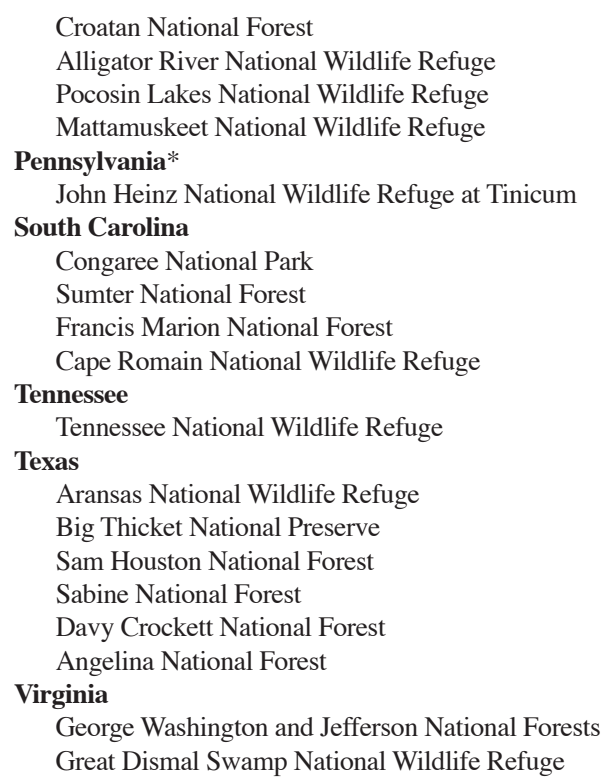

$\begin{array}{rrl}64,700 & \text { X } & \text { Graeter 2008 } \\ 61,924 & \text { X } & \text { Gaul and Mitchell 2007 } \\ 44,559 & \text { X } & \text { Phillips 2007 } \\ 20,305 & \text { X } & \text { Freske 2008 } \\ & & \\ 405 & \text { X } & \text { US Fish and Wildlife } \\ & & \\ 10,743 & \text { X } & \text { Congaree National Park } \\ 150,000 & \text { L } & \text { Range map } \\ 104,700 & \text { X } & \text { Beane et al. 2010; Francis Marion National Forest } \\ 26,825 & \text { X } & \text { Nilius 2010 } \\ & & \\ 20,784 & \text { X } & \text { Littrell 2010 } \\ & & \\ 46,412 & \text { X } & \text { Jones 2006 } \\ 44,145 & \text { X } & \text { Parks et al. 1936, 1938 } \\ 65,900 & \text { X } & \text { Sam Houston National Forest } \\ 65,100 & \text { L } & \text { Range map } \\ 65,000 & \text { L } & \text { Range map } \\ 61,990 & \text { L } & \text { Range map } \\ & & \\ 724,764 & \text { L } & \text { Range map } \\ 45,002 & \text { X } & \text { Bard 2006 }\end{array}$

The incubation period of $K$. subrubrum is variable, and hatching may be delayed depending on location. Incubation time lasts approximately 100 days and is thought to be negatively correlated with latitude (Iverson 1979; Gibbons 1983; Houseal and Carr 1983). The long incubation period in this species was thought to explain the high proportion of non-polar lipids in its eggs (Nagle et al. 1998). In South Carolina,K.subrubrum nests experienced a strong fluctuation in diel temperatures (Bodie et al. 1996). Their shallow (mean $=7.54 \mathrm{~cm}$ ) nests placed in shaded areas provided protection from potential lethal temperatures $>40^{\circ} \mathrm{C}$ (Bodie et al. 1996). On two occasions in extreme southern Louisiana, a single egg of K. subrubrum was found partially exposed under leaf litter (Anderson and Horne, 2009). Possible reasons for this phenomenon were reduced gas exchange in the clay soil substrate of the area, difficulty in digging in the compact clay soil, or anomalously by females that oviposited after earlier attempts at nest construction failed (Anderson and Horne 2009). Because the eggs were found on dikes were rarely subject to flooding, actively avoiding nest construction underground did not seem likely (Anderson and Horne 2009).

In South Carolina, hatchlings overwinter in the nest and emerge the following spring (Gibbons and Nelson 1978), but it is unknown, though suspected, that this phenomenon occurs in Florida. Hatching is generally thought to occur during August-September (Ernst et al. 1994); however, in Florida, where the nesting season is long, recently hatched individuals have been found during December-February (Iverson 1977). Hatchlings in Arkansas averaged $22.0 \mathrm{~mm}$ CL and $18.4 \mathrm{~mm}$ PL (Iverson 1979). In a mixed sample of K. s. subrubrum and K. s. steindachneri from Florida, female hatchlings averaged $18.2 \mathrm{~mm} \mathrm{PL}$, and male hatchlings averaged $17.6 \mathrm{~mm}$ PL (Ernst et al. 1973). A single hatchling K. s. steindacheri from Orlando, Florida, measured $22 \mathrm{~mm}$ CL and $18 \mathrm{~mm}$ PL (Lardie 1975).
Population Status. - Population sizes vary widely in this species depending on the habitat: 8.2 turtles/ha in a farm pond in South Carolina (Congdon et al. 1986), 22-56 turtles/ ha in a Carolina Bay in South Carolina (Gibbons 1983), 64 and 104 turtles/ha in a creek in Oklahoma (Mahmoud 1969), 58-160 turtles/ha in Alabama farm ponds (Scott 1976), 470 turtles/ha in a fertilized farm pond in Alabama (Stone et al. 1993), and 33-92 turtles/ha in ponds in southeastern New York (Larese-Casanova 1999). Biomass of K. subrubrum was estimated to be $0.7 \mathrm{~kg} / \mathrm{ha}$ in a pond and $3.7 \mathrm{~kg} / \mathrm{ha}$ in a Carolina Bay in South Carolina (Congdon et al. 1986), $2.1-11.1 \mathrm{~kg} / \mathrm{ha}$ in ponds in New York (Larese-Casanova 1999), and , as calculated by Iverson (1982) from Mahmoud's (1969) study, $25.9 \mathrm{~kg} / \mathrm{ha}$ in a creek in Oklahoma. These findings corroborated the suggestion that trophic position has less of an effect on biomass of a species than the habitat quality and the body size and population structure of the species (Congdon et al. 1986). Ernst et al. (1994) suggested that permanent streams support more K. subrubrum than do temporary aquatic systems, but this has not been documented to be a rangewide phenomenon and does not appear to be true on the Savannah River Site in the Upper Coastal Plain of South Carolina (Gibbons, pers. obs.). Changes in population sizes and physical condition of K. subrubrum in two Alabama farm ponds were thought to have been related in part to both superior colonization ability in initially finding the ponds and subsequently to land use conditions associated with them (Stone et al. 1993).

Sex ratios of $K$. subrubrum tend towards unity in large samples, with adults often dominating captures in field studies. In South Carolina, the sex ratio of K. s. subrubrum was found to be 1:1 (Gibbons 1983; Tuberville et al. 1996), as it was in New York (Larese-Casanova 1999). In three Oklahoma populations of K. s. hippocrepis, females outnumbered males $(1: 1.5,1: 1.5,1: 1.8)$ (Mahmoud 1969); 
however, the small sample sizes of the latter study led Ernst et al. (1994) to question the applicability of the estimated sex ratios to the whole population. The apparent scarcity of juveniles at many sites across the range of this species has raised the question of sampling bias as a possible reason for this observed phenomenon (Ernst et al. 1994).

Variability in reproductive output can affect the dynamics of K. subrubrum populations. In South Carolina, annual fecundity was subject to variation in the number of clutches produced and the number of females laying eggs each year but not clutch size (Gibbons 1983).

Kinosternon subrubrum can live for several decades, thereby contributing reproductively for potentially $25 \mathrm{yrs}$ or more. Maximum longevity in the wild is thought to exceed 30 yrs (Gibbons 1983; Parker 1996), and in a life table constructed for K. s. subrubrum in South Carolina annual survival for both sexes approached $90 \%$, with some turtles projected to live to nearly 40 yrs of age (Frazer et al. 1991). However, the captive longevity record is 18.3 yrs, based on a turtle acquired as an adult (Slavens and Slavens 2000).

Kinosternon subrubrum can range from uncommon to rare relative to other kinosternid turtles and aquatic turtles generally. In North Carolina, Failey et al. (2007) found that it comprised $10.4 \%$ and $3.5 \%$ of all turtles (six species) and $100 \%$ and $67 \%$ of all kinosternids in golf course ponds and farm ponds, respectively. It totaled $4.4 \%$ of all turtle captures (and $26.3 \%$ of all kinosternid captures) in Texas (Riedle et al. 2015). It totalled $10.9 \%$ of kinosternid turtles and $1.1 \%$ of all aquatic turtles traversing or attempting to traverse a road that bisected a lake in northwestern Florida (Aresco 2005) and $12.7 \%$ of the three kinosternid turtles and $8.0 \%$ of all turtles found as roadkills on a road bisecting a prairie in north-central Florida (Smith and Dodd 2003). In a central Florida lake, it was the fourth most abundant species but accounted for less than $2 \%$ of all captured turtles (Bancroft et al. 1983). As measured by collection records and natural history observation cards in Everglades Regional Collection Center of Everglades National Park, K. s. steindachneri, like the Common Musk Turtle (Sternotherus odoratus), is scarce compared to K. baurii in the southern Everglades.

Kinosternon subrubrum is an omnivore with primarily carnivorous tendencies, and its diet is similar in widely separated populations. Insects, crustaceans, and mollusks dominated the diet of this species in Oklahoma (Mahmoud 1968), North Carolina (Brown 1992), New York (LareseCasanova 1999) and central Florida (Bancroft et al. 1983). Crayfish and seeds have been found in stomachs of Virginia K. s. subrubrum (Mitchell 1994) and in K. subrubrum from Alabama (Graham and Sorrell 2008). Individuals from Alabama have been seen feeding on frogs (Mount 1975), an adult was seen scavenging a dead Southern Leopard Frog (Lithobates sphenocephalus) in Arkansas (Meshaka, pers. obs.), and snails were found in the stomach of an individual in Louisiana (Dundee and Rossman 1989). Schmidt and Inger (1957) reported dead fish in the diet of this species, and Pope (1939) included earthworms. A female from Tennessee was found to have ingested portions of a shed skin of a snake presumed to have been Nerodia sipedon (Steen et al. 2012). Food is eaten at body temperatures (BT) of $13-38^{\circ} \mathrm{C}$ (Mahmoud 1969) with higher energy demands reported at higher BTs (Litzgus and Hopkins 2003).

Kinosternon subrubrum faces a wide range of predators throughout its potentially long life. Vertebrates, such as kingsnakes (Lampropeltis), opossums (Didelphis), raccoons (Procyon), crows (Corvus), gar(Lepisosteus), and blue crabs (Callinectes) are known predators of the species (Ernst and Lovich 2009). Kellogg (1929), Giles and Childs (1949) and Nifong (2014) reported K. subrubrum in the diet of the American Alligator (Alligator mississippiensis). Zimorski et al. (2013) reported attempted predation on an adult by several Whooping Cranes (Grus americana). In one instance, a live hatchling was removed from the stomach of a racer (Coluber constrictor; Brown 1979).

The shape and color of its carapace and its preference for vegetation cover could provide $K$. subrubrum with crypsis as an effective primary defense mechanism. Its production of musk is not as pronounced as that of S.odoratus; however, a provoked individual can defend itself with its sharp beak, strong jaws, and lengthy neck. Associated with terrestrialpredator deterrence, musk secretion under water might serve other functions in K. s. subrubrum (Cordero 2011). Its ability to partially or entirely close its shell and the presence of a thick shell were thought to have been helpful in preventing a successful predation attempt by a nesting Bald Eagle (Mitchell et al. 2006).

Egg survivorship of $K$. subrubrum nests in American Alligator nests may be at risk if nest opening activities by the Alligator precede hatching of K. subrubrum eggs (Deitz and Jackson 1979). A high three-year mean nest predation rate of $84.2 \%$ in South Carolina was not associated with density of nests (Burke et al. 1998).

Threats to Survival. - Habitat loss and road mortality are two well-documented threats to K. subrubrum. Mass mortality events can be profound following rain-related movements (Crawford and Doyle 2010). Cumulative mortality can result in local extirpations. For example, in New York, K. s. subrubrum, once known from at least 20 freshwater and estuarine sites (Latham 1969; Craig et al. 1980; A. Breisch, pers. comm.), presently exists only in five populations on Long Island, and possibly one additional population on Staten Island (A. Breisch, pers. comm.). This represents a loss of $75 \%$ of New York mud turtle populations since the 1930 s, the declines attributed to the effect of habitat alteration and degradation resulting from sprawling development on Staten Island and along Long 
Island's southern shore, road mortality, and by altered salinity regimes resulting from the permanent breaching of barrier beaches by catastrophic hurricanes (A. Breisch, unpubl. data). The negative effects of weather events aggravated by climate change and sea level rise place insular populations of K. subrubrum particularly at risk on Atlantic Coast barrier islands, where this species was found to be successful (Gibbons and Coker 1978). Surprisingly, Gibbons et al.(1983) could detect no impact of drought cycles on reproduction or terrestrial migration in this species. Kinosternon subrubrum was one of five North American mud turtle species whose geographic ranges were examined in relation to projected future climate change (Butler et al. 2016). For this species, suitable habitat was expected to increase, accompanied by a shift northward in distribution, evident by the mid- to late 2000s (Butler et al. 2016).

The loss of K. s. steindachneri in a central Florida lake was associated with shoreline alterations for a housing development (Bancroft et al. 1983). Roads bisecting aquatic habitat have had profound negative effects on aquatic turtles, including K. subrubrum (Smith and Dodd 2003; Aresco 2005), and populations in urbanized areas were associated with lower survivorship (Eskew et al. 2010).

Meshaka and Gibbons (2006) noted a near absence of population studies of K. s. steindachneri in Florida, thereby precluding an evaluation of its status anywhere in the state. In Florida, where habitat loss and road construction associated with the rapid development of the state adversely affect this regionally-distinct endemic subspecies, the inability to evaluate its status was thought to warrant its treatment at least as a separate conservation priority, if not a separate species (Meshaka and Gibbons 2006). Winzeler et al.(2015) reported systemic ranaviral infection in a K. subrubrum from a site in South Carolina where ranaviruses were present in several amphibian populations.

Conservation Measures Taken. - The species is considered State endangered in Indiana, New York, and Pennsylvania, and a species of greatest conservation need in Kentucky. It occurs in many protected areas - Table 1 lists the National Parks, National Preserves, National Forests, and National Wildlife Refuges where it has been recorded or projected to occur. It is not listed on the CITES Appendices, and the IUCN Red List assessed it as Least Concern in 2011 (van Dijk 2011).

Conservation Measures Proposed. - Several studies have provided the kinds of useful data necessary to make effective management decisions on the conservation of $K$. subrubrum. Undeveloped upland habitat zones of 1500 $\mathrm{ft}(457.2 \mathrm{~m})$ from the edge of wetlands inhabited by $K$. s. subrubrum were recommended for populations in an increasingly suburbanized area of Long Island (Cavanaugh and Loop 1988). The upland habitat zone would be effective if cleared of physical obstructions to the overland movements of the species. Cavanaugh and Loop (1988) also noted the danger to K. s. subrubrum by roads and human commensal species associated with increased development of the area. Undeveloped upland habitat zones of $73 \mathrm{~m}$ could protect $90 \%$ of nesting sites and those of $275 \mathrm{~m}$ could protect $100 \%$ of nesting sites of K. s. subrubrum in South Carolina (Burke and Gibbons 1995). A range of 127-289 $\mathrm{m}$ from the edge of an aquatic site was considered core terrestrial habitat for reptiles, including K. subrubrum (Semlitsch and Bodie 2003). At a lake in northwestern Florida, a temporary drift fence connected to existing culverts reduced turtle mortality, including that of $K$. subrubrum, from 11.9 turtles $/ \mathrm{km} /$ day to 0.09 turtles $/ \mathrm{km} /$ day (Aresco 2005). The effectiveness of the fence was profound: a probability model predicted that at least $98 \%$ of the turtles diverted by the fence would otherwise have been killed (Aresco 2005).

As with most species of the world's turtles, broad conservation and management decisions cannot be made for K.subrubrum throughout most of its geographic range without further ecological information on population dynamics of the species and its responses to environmental variability.

Captive Husbandry. - Reptiles Magazine has provided an online care sheet for K.subrubrum. Hofer (2002) discussed the care and breeding of K. s. steindachneri.

Current Research. - Wallops Island, Virginia, is the site of an ongoing demographic study of K. s. subrubrum that inhabits shallow ditches of fluctuating water depth and salinity (Pablo R.Delis and Meshaka, unpubl.data). Ongoing M.S. thesis work by Safiya Ladidi Abubakar of Shippensburg University examines several life history traits of the Wallops Island population.

Acknowledgments. - Manuscript preparation was aided by the Environmental Remediation Sciences Division of the Office of Biological and Environmental Research, U.S. Department of Energy through Financial Assistant Award No. DE-FC09-96SR18546 to the University of Georgia Research Foundation. Vincent Burke and Alvin Breisch provided information and useful comments and reviews on the manuscript, and Richard D. Bartlett and Pablo R. Delis provided photographs.

\section{LITERATURE CITED}

Anderson, N.J. ANd Horne, B.D. 2009. Observations on the nesting ecology of the Mississippi mud turtle, Kinosternon subrubrum hippocrepis Gray. Southeastern Naturalist 8:563-565.

Anderson, P.K. 1965. The Reptiles of Missouri. Columbia, MO: University of Missouri Press, $330 \mathrm{pp}$.

ARESCO,M.J.2005. Mitigation measures to reduce highway mortality of turtles and other herpetofauna at a north Florida lake. Journal of Wildlife Management 69:549-560.

AtZert, S.P. 2004. Edwin B. Forsythe National Wildlife Refuge Comprehensive Conservation Plan.Hadley,MA: US Department of the Interior and USFish and Wildlife Service, Northeast Region. 
Bancroft, G.T., Godley, J.S., Gross, D.T., RoJas, N.N., SutPhen, D.A., AND McDiarmid, R.W. 1983. The herpetofauna of Lake Conway: species accounts. Vicksburg, MS: US Army Corps of Engineers, Miscellaneous Papers, A-83-5, Army Engineer Waterways Experiment Station.

BARD, S.C. 2006. Great Dismal Swamp National Wildlife Refuge Comprehensive Conservation Plan.Hadley,MA: US Department of the Interior and US Fish and Wildlife Service,Northeast Region.

BAUR, G. 1893. Two new species of North American Testudinata. American Naturalist 27:675-677.

Beane, J.C., Braswell, A.L., Mitchell, J.C., and Palmer, W.M. 2010. Amphibians and Reptiles of the Carolinas and Virginia. Chapel Hill, NC: University of North Carolina Press.

BeLL, T. 1825. A monograph of the tortoises having a moveable sternum, with remarks on their arrangement and affinities. Zoological Journal 2:299-310.

BenNetT, D.H. 1972. Notes on terrestrial wintering of mud turtles (Kinosternon subrubrum). Herpetologica 28:245-247.

Bennett, D.H., GibBons, J.W., and Franson, J.C. 1970. Terrestrial activity in aquatic turtles. Ecology 51:738-740.

Bodie, J.R., SMith, K.R., AND BuRKE, V.J. 1996. A comparison of diel nest temperature and nest site selcection for two sympatric species of freshwater turtles. the american Midland Naturalist 136:181-186.

Bonnaterre, P.J. 1789. Tableau Encyclopédique et Méthodique des Trois Règnes de la Nature. Erpétologie. Paris: Panckoucke, Hôtel de Thou, 70 pp.

Bourque, J.R.2016.New mud turtles (Kinosternidae, Kinosternon) from the middle-late Miocene of the United States. Journal of Paleontology 89:821-844.

Bourque, J.R. And Schubert, B.W. 2015. Fossil musk turtles (Kinosternidae, Sternotherus) from the Miocene-early Pliocene (Hemphillian) of Tennessee and Florida. Journal of Vertebrate Paleontology 35(1):doi:10.1080/02724634.2014.885441.

BRown, E.E. 1979. Some snake food records from the Carolinas. Brimleyana 1:113-124.

BROwn,E.E. 1992. Notes on amphibians and reptiles of the western Piedmont of North Carolina. Journal of the Elisha Mitchell Scientific Society 108:38-54.

Buhlmann, K.B. and GibBons, J.W. 2001. Terrestrial habitat use by aquatic turtles from a seasonally fluctuating wetland: implications for wetland conservation boundaries. Chelonian Conservation and Biology 4:115-127.

Buhlmann, K.A., Akre, T.S., Iverson, J.B., Karapatakis, D., MitTermeIr,R.A., Georges,A.,Rhodin,A.G.J., vAN DiJK,P.P., AND GibBons, J.W. 2009. A global analysis of tortoise and freshwater turtle distributions with identification of priority conservation areas. Chelonian Conservation and Biology 8:116-149.

Burke, V.J. And GibBons, J.W. 1995. Terrestrial buffer zones and wetland conservation: a case study of freshwater turtles in a Carolina Bay. Conservation Biology 9:1365-1669.

Burke, V.J., GibBons, J.W., And Greene, J.L. 1994. Prolonged nesting forays by common mud turtles (Kinosternon subrubrum). American Midland Naturalist 131:190-195.

Burke, V.J., Rathburn, S.L, Bodie, J.R., and Gibbons, J.W. 1998. Effect of density on predation rate for turtle nests in a complex landscape. Oikos 83:3-11.

Butler, C.J., Stanila, B.D., Iverson,J.B., Stone,P.A., and Bryson, M.2016.Projected changes in climatic suitability for Kinosternon turtles by 2050 and 2070. Ecology and Evolution 6: 7690-7705.

Cagle,F.R.and Chaney,A.H.1950.Turtle populations in Louisiana. The American Midland Naturalist 43:383-388.

CARR, A.F. 1940. A contribution to the herpetology of Florida.
University of Florida Publications, Biological Sciences Series 3:1-118.

Cavanaugh, J. and Loop, K. 1988. A radio-telemetry study of Kinosternon subrubrum subrubrum, Wehrmans Pond, Southampton, New York. Delmar, NY: Unpublished report, Endangered Species Unit, New York Department of Environmental Conservation.

Congaree National Park. 2016. Mammals, reptiles, \& amphibians partial list. https://www.nps.gov/cong/planyourvisit/upload/ Mammals,\%20Reptiles,\%20Amphibians\%20Partial\%20 Species\%20List.pdf.

Congdon, J.D. And Gibbons, J.W. 1985. Egg components and reproductive characteristics of turtles: relationships to body size. Herpetologica 41:194-205.

Congdon, J.D., GreEne, J.L., AND GibBons, J.W. 1986. Biomass of freshwater turtles: a geographic comparison. American Midland Naturalist 115:165-173.

Constantino, G. 2006. Okefenokee National Wildlife Refuge Comprehensive Conservation Plan.Atlanta, GA: US Department of the Interior and US Fish and Wildlife Service, Southeast Region.

Coppola, A.J. 2013. Prime Hook National Wildlife Refuge Comprehensive Conservation Plan. Hadley, MA: US Department of the Interior and US Fish and Wildlife Service, Northeast Region.

CORDERo,G.A. 2011. Kinosternon subrubrum (Eastern MudTurtle). Musking. Herpetological Review 42:422.

Cordero, G.A., Quinlan, M., Blackstone, S., and Swarth, C.W. 2012B. Kinosternon subrubrum (Eastern Mud Turtle). Overwintering. Herpetological Review 43:327.

Cordero, G.A., Reeves, R., and Swarth, C.W. 2012A. Long distance aquatic movement and home-range size of an eastern mud turtle, Kinsoternon subrubrum, population in the MidAtlantic region of the United States. Chelonian Conservation and Biology 11:121-124.

Cordero, G.A. and Swarth, C.W. 2010. Notes on the movement and aquatic behavior of some kinosternid turtles. Acta Zoológica Mexicana 26:233-235.

Craig,R.J.,Klemens, M.W., and Craig, S.S. 1980. The northeastern range limit of the eastern mud turtle Kinosternon s. subrubrum (Lacépède). Journal of Herpetology 14:295-297.

Crawford, R.L. AND doyle, M.J. 2010. Kinosternon subrubrum (Eastern Mud Turtle). Mass movement and mortality. Herpetological Review 41:71.

DeITZ, D.C. AND JACKSON, D.R. 1979. Use of American Alligator nests by nesting turtles. Journal of Herpetology 13:510-512.

Duellman, W.E. AND Schwartz, A. 1958. Amphibians and reptiles of southern Florida. Bulletin of the Florida State Museum, Biological Sciences 3:181-324.

Duever, M. 1972. The striped mud turtle (Kinosternon bauri Garman) in South Carolina. Herpetological Review 4:131.

Dundee, H.A. And Rossman, D.A. 1989. The Amphibians and Reptiles of Louisiana. Baton Rouge, LA: Louisiana State University Press.

Enge, K.M. AND Wood, K.N. 2001. Herpetofauna of Chinsegut Nature Center, Hernando County, Florida. Florida Scientist 64:283-305.

ERnst, C.H. AND Barbour, R.W. 1989. Turtles of the World. Washington, DC: Smithsonian Institute Press, 313 pp.

ERnst, C.H. And Lovich, J.E. 2009. Turtles of the United States and Canada. Second Edition. Baltimore, MD: Johns Hopkins University Press, $827 \mathrm{pp}$.

Ernst, C.H., Barbour, R.W., And Butler, J.R. 1972. Habitat preference of two Florida turtles, genus Kinosternon.Transactions of the Kentucky Academy of Sciences 33:41-42. 
ERnst, C.H., Barbour, R.W., ERnst, E.M., AND ButLer, J.R. 1973. Growth of the mud turtle, Kinosternon subrubrum, in Florida. Herpetologica 29:247-250.

ERnst, C.H., Barbour, R.W., ERnst, E.M., AND Butler, J.R. 1977. Subspecific variation and intergradation in Florida Kinosternon subrubrum. Herpetologica 30:317-320.

ERnst, C.H., Lovich, J.E., AND Barbour, R.W. 1994. Turtles of the United States and Canada. Washington, DC: Smithsonian Institution Press, $578 \mathrm{pp}$.

ERnst, C.H., Belfit, S.C., SeKsCienski, S.W., AND LAEMmERZAhl, A.F. 1997a.The amphibians and reptiles of Ft. Belvoir and northern Virginia. Bulletin of the Maryland Herpetological Society 33:1-62.

ERnst, C.H., Lovich, J.E., LaemmerZahl, A.F., AND SEKSCIENSKi, S. 1997b. A comparison of plastron scute lengths among members of the box turtle genera Cuora and Terrapene. Chelonian Conservation and Biology 2:603-607. (check if in text)

Ernst, C.H., Creque, T.R., and Hansknecht, K.A. 2001. Kinosternon subrubrum (Eastern Mud Turtle). Early nesting. Herpetological Review 32:103-104.

Eskew, E.A., Price, S.J., And Dorcas, M.E. 2010. Survival and recruitment of semi-aquatic turtles in an urbanized region. Urban Ecosyst 13:365-374.

Ewert, M.A., Jackson, D.R., And Guyot, G. 2004. Kinosternon baurii (Striped Mud Turtle). Herpetological Review 35:80.

Failey, E.L., McCoy, J.C., Price, S.J., and Dorcas, M.E. 2007. Ecology of turtles inhabiting golf course and farm ponds in the western Piedmont of North Carolina. Journal of the North Carolina Academy of Science 123:221-232.

FoLK,R.H.ANDBALES,C.W.1982.An evaluation of wildlife mortality resulting from aerial ignition prescribed burning. Proceedings of the Annual Conference of the Southeastern Association of Fish and Wildlife Agencies 36:643-646.

Francis Marion National Forest. http://metro-naturalist.com/ South_Carolina/FrancisMarionNationalForest7.html.

Frazer, N.B.,GibBons, J.W., AND GreEne,J.L.1991 .Life history and demography of the common mud turtle Kinosternon subrubrum in South Carolina, USA. Ecology 72:2218-2231.

Freske, B. 2008. Mattamuskeet National Wildlife Refuge Comprehensive Conservation Plan.Atlanta, GA: US Department of the Interior and USFish and Wildlife Service, SoutheastRegion.

Gaul, R.W., JR. AND Mitchell, J.C. 2007. The herpetofauna of Dare County, North Carolina: History, natural history, and biogeography. Journal of the North Carolina Academy of Science 123:65-109.

GiBBons,J.W. 1970.Terrestrial activity and the population dynamics of aquatic turtles. American Midland Naturalist 83:404-414.

GibBons, J.W. 1983. Reproductive characteristics and ecology of the mud turtle, Kinosternon subrubrum (Lacépède). Herpetologica 39:254-271.

GibBons, J.W. AND CoKER, J.W. 1978. Herpetofaunal colonization patterns of Atlantic Coast barrier islands. The American Midland Naturalist 99:219-233.

Gibbons, J.W. And Lovich, J.E. 1990. Sexual dimorphism in turtles with emphasis on the slider turtle (Trachemys scripta). Herpetological Monographs 4:1-29.

GibBons,J.W. AND NELSON,D.H.1978. The evolutionary significance of delayed emergence from the nest by hatchling turtles. Evolution 32:297-303

Gibbons, J.W., Greene, J.L., And Congdon, J.D. 1983. Droughtrelated responses of aquatic turtle populations. Journal of Herpetology 17:242-246.

Giles, L.W. AND CHILDS, V.L. 1949. Alligator management of the
Sabine National Wildlife Refuge.Journal of Wildlife Management $13: 16-28$

Gmelin, J.F. 1789 [“1788”]. Caroli a Linné, Systema Naturae per regna tria naturae secundum classes, ordines, genera, species, cum characteribus, differentiis, synonymis, locis. Ed. 13. Tom. I. Pars III. Leipzig: G.E. Beer, Ed. 13, 1(3):1033-1516.

Graeter, G.J. 2008. Western North Carolina reptile inventories. Annual Performance Report, Wildlife Diversity Program, Division of Wildlife Management, North Carolina Wildlife Resources Commission.

Graham, S.P. And Sorrell, G.G. 2008. Kinosternon subrubrum (Eastern Mud Turtle). Diet. Herpetological Review 39:218.

Grant,C. 1935. Secondary sexual differences and notes on the mud turtle, Kinosternon subrubrum in northern Indiana. American Midland Naturalist 16:798-800.

Gray, J.E. 1844. Catalogue of the Tortoises, Crocodiles, and Amphisbaenians in the Collection of the British Museum. London: Edward Newman, 80 pp.

Gray, J.E. 1856. On some new species of freshwater tortoises from North America, Ceylon and Australia, in the collection of the British Museum. Proceedings of the Zoological Society of London 1855[1856]:197-202.

GraY, J.E. 1869. Notes on the families and genera of tortoises (Testudinata), and on the characters afforded by the study of their skulls. Proceedings of the Zoological Society of London 1869:165-225.

GunzBurger, M.S., Dodd, C.K.,JR.,B ARICHIVICH,W.J., AND STAIGER, J.S.2005. Southeast amphibian research and monitoring initiative 2005 annual report. US Geological Survey Report, Florida Integrated Science Center, 96 pp.

HaRden, L.A. AND DorCas, M.E. 2008. Using thermal biology thermal biology to Investigate habitat use and activity of mud turtles (Kinsoternon subrubrum) on a golf course.Pp.321-323 In: Urban Herpetology. R.E. Jung and Mitchell, J.C. (eds.). Society for the Study of Amphibians and Reptiles, Salt Lake City, Utah.

Harden, L.A., Price, S.J., and Dorcas, M.E. 2009. Terrestrial activity and habitat selection of eastern mud turtles (Kinosternon subrubrum) in a fragmented landscape: implications for habitat management of golf courses and other suburban environments. Copeia 2009:78-84.

HIBBARD, C.W. 1936. The amphibians and reptiles of Mammoth Cave National Park proposed. Transactions of the Kansas Academy of Science 39:277-281.

Hofer, A. 2002. Keeping and breeding of the Florida mud turtle Kinosternon subrubrum steindachneri (Siebenrock, 1906). In: H. Artner, H., B. Farkas, B., and V. Loehr, V. (Eds.). Turtles Proceedings: International Turtle and Tortoise Symposium Vienna 2002. Frankfurt am Main, Germany: Edition Chimaira, pp. 244-249.

Homyack, J.A., O'Bryan, C.J., Thornton, J.E., ANd B ALDwin, R.F. 2016. Community occupancy of herpetofauna in roadside ditches in a managed pine landscape. Forest Ecology and Management 361:346-357.

Houseal, T.W. AND CARR, J.L. 1983. Notes on the reproduction of Kinosternon subrubrum (Testudines: Kinosternidae) In East Texas. The Southwestern Naturalist 28:237-248.

Huestis, D.L. And MeYlan, P.A. 2004. The turtles of Rainbow Run (Marion County,Florida): observations on the genus Pseudemys. Southeastern Naturalist 3:595-612.

ICZN [INTERNATIONAL COMMISSION ON ZOOLOGICAL NOMENCLATURE]. 2005. Opinion 2104 (Case 3226). Lacepède, B.G.É. de la V., 1788, Histoire Naturelle de Quadrupèdes Ovipares: rejected as a non-binomial work. Bulletin of Zoological Nomenclature 62:55. 
IVERson, J.B. 1977a. Kinosternon subrubrum. Catalogue of American Amphibians and Reptiles 193.1-4.

IvERSON, J.B. 1977b. Reproduction in freshwater and terrestrial turtles of North Florida. Herpetologica 33:205-212.

IvERSON, J.B. 1979. Reproduction and growth of the mud turtle, Kinosternon subrubrum (Reptilia, Testudines, Kinosternidae) in Arkansas. Journal of Herpetology 13:105-111.

IvERSON, J.B. 1982. Biomass in turtle populations: a neglected subject. Oecologia (Berlin) 55:69-76.

Iverson, J.B. 1986. A Checklist with Distribution Maps of the Turtles of the World. Richmond, IN: Paust Printing, 283 pp.

IvERSON, J.B. 1992. A Revised Checklist with Distribution Maps of the Turtles of the World. Richmond,IN: Privately printed, $363 \mathrm{pp}$.

Iverson,J.B.,LE,M., AND IngRAM, C. 2013. Molecular phylogenetics of the mud and musk turtle family Kinosternidae. Molecular Phylogenetics and Evolution 69:929-939.

Jensen, J.B., Camp, C.D., Gibbons, J.W., and Elliot, M.J. (Eds.). 2008. Amphibians and Reptiles of Georgia. Athens, GA: University of Georgia Press.

Johnson, T.R. 1987. The Amphibians and Reptiles of Missouri. Jefferson City, MO: Missouri Department of Conservation, $368 \mathrm{pp}$.

JONES, C. 2006. Geographic distribution: Kinosternon subrubrum hippocrepis (Mississippi Mud Turtle). Herpetological Review 37:492.

KeLlOGG,R. 1929. The habits andeconomic importance of alligators. US Department of Agriculture, Technical Bulletin 147:1-36.

Kentucky's Comprehensive Wildlife Conservation Strategy. 2013. Kentucky Department of Fish and Wildlife Resources. http://fw.ky.gov/WAP/Pages/Default.aspx.

KLEMENS, M.W. 1990. The herpetofauna of southwestern New England. Ph.D. Dissertation, University of Kent, Canterbury, UK.

Klemens, M.W. 1993. The amphibians and reptiles of Connecticut and adjacent regions. Bulletin of the State Geological and Natural History Survey of Connecticut 112:1-318.

Knudsen, B. 2013. Patuxent Research Refuge Comprehensive Conservation Plan. Hadley, MA: US Department of the Interior and US Fish and Wildlife Service, Northeast Region.

Krysko, K.L., Enge, K.M., Donlan, E.M., Golden, E.A., Burgess, J.P., AND LARSEN, K.W. 2010. The non-marine herpetofauna of Key Biscayne, Florida. Herpetological Conservation and Biology 5:132-142.

Krysko, K.L., Enge, K.M., And Moler, P.E. 2011. Atlas of amphibians and reptiles in Florida. Final Report of Project Agreement (\#08013) to the Florida Fish and Wildlife Conservation Commission, 524 pp.

LACEPÈDE, B.G.E. DE. 1788. Histoire Naturelle des Quadrupèdes Ovipares et des Serpens. Tome Premier. Paris: Hôtel de Thou, $651 \mathrm{pp}$. [octavo edition, $8^{\circ}$ ].

LAMB, T. 1983. The striped mud turtle (Kinosternon baurii) from South Carolina: a confirmation through multivariate character analysis. Herpetologica 39:383-390.

LAmB, T. AND Lovich, J. 1990. Morphometric validation of the striped mud turtle (Kinosternon baurii) in the Carolinas and Virginia. Copeia 1990:613-618.

LAMB, T. AND Lovich, J. 1995. Morphometric similarity between the turtles Kinosternon subrubrum hippocrepis and K. baurii. Journal of Herpetology 29:621-624.

LARDIE, R.L. 1975. Observations on reproduction in Kinsosternon. Journal of Herpetology 9:260-264.

LARESE-CASANOva, M. 1999. The ecology of an insular population of Eastern Mud Turtles (Kinostemon subrubrum subrubrum). M.S. Thesis, University of Connecticut.
Latham, R. 1969. The eastern mud turtle and stinkpot on eastern Long Island. Engelhardtia 2:1-2.

LindSAY, S.D. AND DORCAS, M.E. 2001. Effects of cattle on reproduction and morphology of pond-dwelling turtles in North Carolina. The Journal of the Elisha Mitchell Scientific Society 117:249-257.

LitTrell, T. 2010. Tennessee National Wildlife Refuge Complex Comprehensive Conservation Plan.Atlanta, GA: US Department of the Interior and US Fish and Wildlife Service, Southeast Region.

LitzGus, J.D. AND Hopkins, W.A. 2003. Effect of temperature on metabolic rate of the mud turtle (Kinosternon subrubrum). Journal of Thermal Biology 38:595-600.

Long, D.J. 2006. Long Island National Wildlife Refuge Complex Comprehensive Conservation Plan.Hadley,MA: US Department of the Interior and US Fish and Wildlife Service, Northeast Region.

Lovich, J.E. AND ERNST, C.H. 1989. Variation in the plastral formulae of selected turtles with comments on taxonomic utility. Copeia 1989:304-318.

Lovich, J.E., Laemmerzahl, A.F., Ernst, C.H., and McBreen, J.F. 1991. Relationships among turtles of the genus Clemmys (Reptilia: Testudines: Emydidae) as suggested by plastron scute morphology. Zoologica Scripta 20:425-429.

Mahmoud, I.Y. 1967. Courtship behavior and sexual maturity in four species of kinosternid turtles. Copeia 1967:314-319.

Mahmoud, I.Y. 1968. Feeding behavior in kinosternid turtles. Herpetologica 24:300-305.

MaHmoud,I.Y.1969.Comparative ecology of the kinosternid turtles of Oklahoma. Southwestern Naturalist 14:31-66.

MaHmoud, I.Y. And KLICKA, J. 1972. Seasonal gonadal changes in kinosternid turtles. Journal of Herpetology 6:183-189.

Mann-KLager,D.P. And PARRIS, R. 1993.Preliminary assessment of the Long Island National Wildlife Refuge Complex environmental contaminants background survey-second year results. New York, NY: US Fish and Wildlife Service.

Means, B.D. 1976a. Survey of the status of amphibians and reptiles of the Apalachicola National Forest, Florida. Report under contract with the US Forest Service, $60 \mathrm{pp}$.

Means, B.D. 1976b. Survey of the status of amphibians and reptiles of the Ocala National Forest, Florida. Report under contract with the US Forest Service, $43 \mathrm{pp}$.

Means, B.D. 1976c. Survey of the status of amphibians and reptiles of the Osceola National Forest, Florida. Report under contract with the US Forest Service, $52 \mathrm{pp}$.

MeshaKa, W.E.,JR. AND GibBons, J.W.2006. Kinosternon subrubrum - Eastern Mud Turtle. In: Meylan, P.A. (Ed.). Biology and Conservation ofFlorida Turtles. Chelonian ResearchMonographs 3:189-196.

Meshaka, W.E., JR. and Layne, J.N. 2015. The herpetology of southern Florida. Herpetological Conservation and Biology 10(Monograph 5):1-353.

Meshaka, W.E., JR., Loftus, W.B., And Steiner, T. 2000. The herpetofauna of Everglades National Park. Florida Scientist 63:84-103.

Minton,S.A.,JR. 1972.Amphibians and Reptiles of Indiana.Monographs of the Indiana Academy of Sciences 3:1-346.

Minton, S.A., JR. 2001. Amphibians and Reptiles of Indiana. Indianapolis, IN: Indiana Academy of Sciences.

Minton, S.A.,JR,List, J.C., AND LodATo, M.J. 1982. Recent records and status of amphibians and reptiles in Indiana. Proceedings of the Indiana Academy of Science 92:489-498.

Mitchell, J.C. 1994. The Reptiles of Virginia. Washington, DC: Smithsonian Institution Press, $352 \mathrm{pp}$.

Mitchell, J.C., Markham, A.C., WatTs, B.D. 2006. Kinosternon 
subrubrum subrubrum (Eastern Mud Turtle). Predation escape. Herpetological Review 37:216-217.

MorkiLl, A. 2009. Lower Florida Keys National Wildlife Refuges Comprehensive Conservation Plan.Atlanta,GA: US Department of the Interior and US Fish and Wildlife Service, SoutheastRegion.

Mount, R.H. 1975. The reptiles and amphibians of Alabama. Auburn,AL:Agricultural Experiment Station, Auburn University.

Musaus, M.J. 2000. Arthur R. Marshall Loxahatchee National Wildlife Refuge Comprehensive Conservation Plan. Atlanta, GA: US Department of the Interior and US Fish and Wildlife Service, Southeast Region.

NAGLE, R.D.,BuRKE,V.J., AND ConGdon,J.D. 1998.Egg componants and hatchling lipid reserves: Parental investment in kinosternid turtles from the southeastern United States. Comparative Biochemistry and Physiology Part B 120:145-152.

National Park Service. 2016. Pine Barrens. http://www. njwildlifetrails.org/PineBarrensTrails/Sites/tabid/1698/Scope/ site/Guide/PINEBARREN/Site/342/Default.aspx;

Nichols, J.T. 1947. Notes on the mud turtle. Herpetologica 3:147-148.

NIFONG, J.C. 2014. Use of marine habitat and food resources by coastal inhabiting Alligator mississippiensis (American alligator): implications for food web and community dynamics. Ph.D. Dissertation, University of Florida, Gainesville.

NiLIus, R. 2010. Cape Romain National Wildlife Refuge Comprehensive Conservation Plan.Atlanta,GA: US Department of the Interior and USFish and Wildlife Service, SoutheastRegion.

PaLmer, W.M. and Braswell,A.L. 1995. Reptiles of North Carolina. London: University of North Carolina Press, 412 pp.

PARKER, W.S. 1996. Age and survivorship of the slider (Trachemys scripta) and the mud turtle (Kinosternon subrubrum) In a Mississippi farm Pond. Journal of Herpetology 30:266-268.

PARKs, H.B. AND CoRy, V.L. 1936. Biological survey of the east Texas Big Thicket area. The fauna and flora of the Big Thicket area. Ed. 1:1-51.

Parks, H.B. AND Cory, V.L. 1938. Biological survey of the east Texas Big Thicket area. The fauna and flora of the Big Thicket area. Ed. 2:1-51.

Phillips, H. 2007. Pocosin Lakes National Wildlife Refuge Comprehensive Conservation Plan.Atlanta,GA: US Department of the Interior and USFish and Wildlife Service, SoutheastRegion.

Pinelands Preservation Alliance. 2016. http://www. pinelandsalliance.org/.

Pope, C.H. 1939. Turtles of the United States and Canada. New York: Alfred A. Knopf, Inc.

Powell, R., Conant, R., And Collins, J.T. 2016. Peterson Field Guide to the Reptiles and Amphibians of the Eastern and Central North America. Fourth Edition. Boston, MA: Houghton Mifflin Harcourt, $494 \mathrm{pp}$.

Purkey, K. 2009. Tensas River National Wildlife Refuge Comprehensive Conservation Plan.Atlanta,GA: US Department of the Interior and US Fish and Wildlife Service, SoutheastRegion.

Rice, A.N. 2004. Diet and condition of American Alligators (Alligator mississippiensis) in three central Florida lakes. M.S. Thesis, University of Florida, Gainesville.

Rice, A.N., Ross, J.P., Woodward, A.R., Carbonneau, D.A., AND PerCIVAL, H.F. 2007. Alligator diet in relation to alligator mortality on Lake Griffin, FL. Southeastern Naturalist 6:97-110.

Rice, K.G., Waddle, J.H., Crockett, M.E., JefFery, B.M., ANd Percival, H.F. 2004. Herpetofaunal inventories of the national parks of South Florida and the Caribbean: Volume I, Everglades National Park. US Geological Survey, Open-File Report, 1065.

Rice, K.G., Waddle, J.H., Jeffery, B.M., Rice, A.N., And Percival,
H.F. 2005. Herpetofaunal inventories of the national parks of South Florida and the Caribbean: Volume III, Big Cypress National Preserve. US Geological Survey, Open-File Report, 1300.

Rice, K.G., W addle, J.H., Crockett, M.E., Bugbee, C.D., JefFery, B.M., AND Percival, H.F. 2007. Herpetofaunal inventories of the national parks of South Florida and the Caribbean: Volume IV, Biscayne National Park. US Geological Survey Open-File Report, 1057.

Richmond, N.D. 1945. Nesting habits of the mud turtle. Copeia 1945:217-219.

Riedle, J.D., Kazmaier, Killian, J., and Littrell, W.B. 2015. Assemblage structure of an eastern Texas aquatic turtle community. Herpetological Conservation and Biology 10:695-702.

Riedle,J.D.,Shipman,P.A.,Fox,S.F., AND LesLie,D.M.2009.Habitat associations of aquatic turtle communities in eastern Oklahoma. Proceedings of the Oklahoma Academy of Science 89:19-30.

Roberts, K.G. And Irwin, K.J. 2012. Arkansas Herpetological Atlas 2012, Distributions of Amphibians and Reptiles. http:// HerpsOfArkansas .com/Herp/Atlas/arherpatlas2012.pdf.

Russell, K.R., Moorman, C.E., Edwards, J.K., Metts, B.S., And GUYN, D.C., JR. 1999. Amphibian and reptile communities associated with beaver (Castor canadensis) ponds and unimpounded streams in the Piedmont of South Carolina. Journal of Freshwater Ecology 14:149-158.

SAmHouston National Forest. https://www.inaturalist.org/check_ lists/91974-Sam-Houston-National-Forest-WMA-Check-List.

Schmidt, K.P AND Inger, R.F. 1957. Living Reptiles of the World. Garden City, New York: Doubleday.

SCHWEIGGer, A.F. 1812. Prodromus monographiae Cheloniorum. Königsberger Archiv für Naturwissenschaft und Mathematik 1:271-368, 406-462.

Scotт, A.F. 1976. Aquatic and terrestrial movements of farm pond populations of the eastern mud turtle (Kinosternon subrubrum subrubrum) in east-centralAlabama.Ph.D.Dissertation, Auburn University.

Semlitsch, R.D. And Bodie, J.R. 2003. Biological criteria for buffer zones around wetlands and riparian habitats for amphibians and reptiles. Conservation Biology 17:1219-1228.

Siebenrock, F. 1906. Eine neue Cinosternum-Art aus Florida. Zoologischer Anzeiger 30:727-728.

SKoREPA,A.C. AND OZMENT, J.E. 1968. Habitat, habits, and variation of Kinosternon subrubrum in southern Illinois. Transactions of the Illinois State Academy of Sciences 61:247-251.

Slavens, F and Slavens, K. 2000. Reptiles and Amphibians in Captivity: Breeding-Longevity-Inventory. Seattle, Washington: Slaveware.

Smith, L.L. AND Dodd, C.K., JR. 2003. Wildlife mortality on U.S. highway 441 across Paynes Prairie, Alachua County, Florida. Florida Scientist 66:128-140.

Sмiтн, P.W. 1961. The amphibians and reptiles of Illinois. Illinois Natural History Survey Bulletin 28:1-298.

Smith, P.W. And List, J. 1950. Notes of Mississippi amphibians and reptiles. American Midland Naturalist 53:115-125.

Spinks, P.Q., Thomson, R.C., Gidis, M., and Shaffer, H.B. 2014b. Multilocus phylogeny of the New-World mud turtles (Kinosternidae) supports the traditional classification of the group. Molecular Phylogenetics and Evolution 76:254-260.

Steen, D.A., Sterrett, S.C., Miller, S.A., and Smith, L.L. 2007. Terrestrial movements and microhabitat selection of overwintering subadult eastern mud turtles (Kinosternon subrubrum) in southwest Georgia. Journal of Herpetology 41:532-555. 
SteEn, D.A.,Webb, K.Q, Vogel,H.J.,Parker, T.D.,Dziadzio,M.C., AND HopkINs, W.A. 2012. Kinosternon subrubrum (Eastern Mud Turtle). Diet. Herpetological Review 43:639.

StILLE, W.T. 1947. Kinosternon subrubrum subrubrum in the Chicago area. Copeia 1947:143.

Stone, P.A., Hauge, J.B., Scott, A.F., Guyer, G., And Dobie, J.L. 1993. Temporal changes in two turtle assemblages. Journal of Herpetology 27:13-23.

TINKLE, D.W. 1959. Observations of reptiles and amphibians in a Louisiana swamp. American Midland Naturalist 62:189-205.

Trauth, S.E.,Robison,H.W., and Plummer,M.V.2004.Amphibians and Reptiles of Arkansas. Fayetteville, AR: University of Arkansas Press.

TTWG [Turtle Taxonomy Working Group] [van Dijk, P.P., Iverson, J.B., Rhodin, A.G.J., ShafFer, H.B., ANd Bour, R.]. 2014. Turtles of the world, 7th edition: annotated checklist of taxonomy, synonymy, distribution with maps, and conservation status. In: Rhodin, A.G.J., Pritchard, P.C.H., van Dijk, P.P., Saumure, R.A., Buhlmann, K.A., Iverson, J.B., and Mittermeier, R.A. (Eds.). Conservation Biology of Freshwater Turtles and Tortoises: A Compilation Project of the IUCN/SSC Tortoise and Freshwater Turtle Specialist Group. Chelonian Research Monographs 5(7):000.329-479.

TTWG [Turtle Taxonomy Working Group] [Rhodin, A.G.J., Iverson, J.B., Bour, R. Fritz, U., Georges, A., Shaffer, H.B., AND VAN DiJk, P.P.]. 2017. Turtles of the World: Annotated Checklist and Atlas of Taxonomy, Synonymy, Distribution, and Conservation Status (8th Ed.). In: Rhodin, A.G.J., Iverson, J.B., van Dijk, P.P., Saumure, R.A., Buhlmann, K.A., Pritchard, P.C.H., and Mittermeier, R.A. (Eds.). Conservation Biology of Freshwater Turtles and Tortoises: A Compilation Project of the IUCN/SSC Tortoise and Freshwater Turtle Specialist Group. Chelonian Research Monographs 7:1-292. doi: 10.3854/ crm.7.checklist.atlas.v8.2017.

Tuberville, T.D., Gibbons, J.W., And Greene, J.L. 1996. Invasion of new aquatic habitats by male freshwater turtles. Copeia 1996:713-715.

US FISH AND WILDLIFE SEARCH. https://catalog.data.gov/group/ fws-gov.

V ALEntine, J.M., JR., Walther, J.R., McCARTney, K.M., AND Ivy, L.M. 1972. Alligator diets on the Sabine National Wildlife Refuge, Louisiana. Journal of Wildlife Management 36:809-815.

VAN DIJK, P.P. 2011. Kinosternon subrubrum. (errata version published in 2016). The IUCN Red List of Threatened Species 2011: e.T163435A97382608.

Walker, D.E., Moler, P.E., Buhlmann, K.A., and Avise, J.C. 1998. Phylogeographic patterns in Kinosternon subrubrum and $K$. baurii based on mitochondrial DNA restriction analyses. Herpetologica 54:174-184.

WEEKs, K. 2008. Survey of priority amphibians and reptiles in the Coastal Plain of North Carolina. Annual Performance Report, Wildlife Diversity Program, Division of Wildlife Management, North Carolina Wildlife Resources Commission.

WiLKInSON, L.R. AND GibBONS, J.W. 2005. Patterns of reproductive allocation: clutch and egg size variation in three freshwater turtles. Copeia 2005:868-879.

Winzeler, M.E., Hamilton, M.T., Tuberville, T.D., and Lance, S.L. 2015. First case of ranvirus and associated morbidity and mortality In an eastern mud turtle Kinosternon subrubrum in South Carolina. Diseases of Aquatic Organisms 114:77-81.

Zimorski, S.E., Perkins, T.L., and Selman, W. 2013. Chelonian species in the diet of reintroduced whooping cranes (Grus americana) in Louisiaana. Wilson Journal of Ornithology 125:42-423.

\section{Citation Format for this Account:}

Meshaka, W.E., JR., Gibbons, J.W., Hughes, D.F., Klemens, M.W., AND IvERSON, J.B. 2017. Kinosternon subrubrum (Bonnaterre 1789) - Eastern Mud Turtle. In: Rhodin, A.G.J., Iverson, J.B., van Dijk, P.P., Buhlmann, K.A., Pritchard, P.C.H., and Mittermeier, R.A. (Eds.). Conservation Biology of Freshwater Turtles and Tortoises: A Compilation Project of the IUCN/SSC Tortoise and Freshwater Turtle Specialist Group. Chelonian Research Monographs 5(10):101.1-16. doi: 10.3854/crm.5.101. subrubrum.v1.2017; www.iucn-tftsg.org/cbftt/. 